\title{
IMPLIKASI KONSEP ŪLŪL 'ILMI DALAM AL-QUR'ĀN TERHADAP TEORI PENDIDIKAN ISLAM (Studi Analisis Terhadap Sepuluh Tafsīr Mu'tabarah)
}

\author{
Nurti Budiyanti*, \\ Ahmad Syamsu Rizal, Elan Sumarna \\ Program Studi Ilmu Pendidikan Agama Islam \\ Fakultas Pendidikan Ilmu Pengetahuan Sosial, Universitas Pendidikan Indonesia \\ *E-mail : nurtibudiyanti11.nb@gmail.com
}

\begin{abstract}
ABSTRAK
Sejatinya, pendidikan merupakan proses pembinaan dan pengembangan potensi manusia secara optimal, bai menyangkut jiwa, akal dan hatinya. Oleh karena itu, proses pendidikan harus mampu menyentuh semua hal tersebut. Hal yang kontradiktif terjadi dalam dunia pendidikan, menunjukkan masih kurangnya kesadaran moral dan spiritual para pelajar serta orang-orang terdidik di Indonesia. Hal ini disebabkan pada praktiknya, sekolah hanya mengejar kelulusan dan intelektualitas peserta didik saja, sehingga tujuan yang dicapaipun bersifat parsial, tidak keseluruhan. Hasilnya pun pendidikan hanya sebatas transfer of knowledge, padahal aspek moral dan spiritual harus menjadi aktualisasi ilmu yang dimilikinya. Al-Qurān memberikan bimbingan secara komprehensif dan integratif terhadap manusia dalam kaitannya terhadap pendidikan, dimana tidak ada dikotomi, melainkan kesatuan dan keseluruhan dalam pendidikan. Bukti dari kesempurnaan al-Qurān tersebut tergambar pada konsep ūlūl 'ilmi. Di dalam penelitian ini, peneliti berupaya menggali dan memahami konsep $\bar{u} l \bar{u} l$ 'ilmi dalam al-Qurān dengan merujuk kepada sepuluh Tafsīr Mu'tabaroh, yang diantaranya ialah: Tafsīr Al-Miṣbāḥ, Tafsīr Fi Zilalil Qư’ān, Tafsīr Ibn Kas̄īr, Tafsīr At-Ṭabari, Tafsīr Al-Qurțubi, Tafsīr AlMaraghi, Tafsīr Al-Aišar, Tafsīr Al-Mizan, Tafsīr Al-Azhar, dan Tafsīr At-Taḥrir Wa Tanwir. Adapun tujuan penelitian ini adalah untuk mengetahui konsep ūlūl 'ilmi dalam al-Qurān yang meliputi makna, karakteristik, peran dan fungsi $\bar{u} l \bar{u} l$ 'ilmi, serta implikasinya terhadap teori pendidikan Islam. Pendekatan yang digunakan adalah pendekatan kualitatif dan secara prosedural metode yang digunakan adalah metode tahlīlī dan muqāran, dengan teknik studi pustaka dalam pengumpulkan data. Adapun teknik analisis data yang digunakan adalah analisis teks dengan menggunakan dilālah dan munāsabah. Berdasarkan penemuan dan analisis dalam penelitian ini didapatkan bahwa makna $\bar{u} l \bar{u} l$ 'ilmi ialah seseorang yang memiliki ilmu berdasarkan realitas, berwawasan luas, kecerdasannya mampu mencapai makrifat, dan hatinya teguh bertauhid karena memiliki tingkatan khasyyah seperti para ulama. Adapun implikasi konsep $\bar{u} l \bar{u} l$ 'ilmi terhadap teori pendidikan Islam meliputi; pendidik, peserta didik, tujuan, peran, fungsi, prinsip, metode, materi dan media pendidikan.
\end{abstract}

Kata Kunci: Ūlūl 'ilmi, Tafsīr Mu'tabaroh, dan Pendidikan Islam. 


\section{PENDAHULUAN}

Alquran diyakini oleh umat manusia sebagai kalām Allah (firman Allah) yang mutlak benar, berlaku sepanjang zaman dan mengandung ajaran serta petunjuk tentang berbagai hal yang berkaitan dengan kehidupan manusia di dunia dan di akhirat nanti. Ajaran dan petunjuk Alquran tersebut berkaitan dengan berbagai konsep yang amat dibutuhkan oleh manusia dalam mengarungi kehidupannya di dunia ini dan di akhirat kelak (Qarḍawĩ, 1998, hlm. 11).

Alquran telah mencangkup seluruh konsep kehidupan, di dalamnya terdapat kandungan yang secara garis besar dapat kita bagi menjadi beberapa hal pokok, yakni akidah, ibadaћ, akhlak, hukum, sejarah, serta ilmu pengetahuan. Hal tersebut menjadikan alasan mengapa Alquran merupakan pedoman hidup manusia, yang harus senantiasa diketahui oleh seluruh umat manusia. Diantara kandungan Alquran yang sangat penting adalah mengenai pendidikan.

Mengingat begitu pentingnya pendidikan, dewasa ini banyak hal yang kontradiktif terjadi dalam dunia pendidikan. Dimana pendidikan yang dilakukan oleh orang tua, guru maupun lembaga lebih menitikberatkan pada intelektualitas saja, sedangkan aspek perilaku dan spiritual luput dari perhatian utama. Sehingga kegagalan kerap terjadi dalam sekmen pendidikan, baik konsep, sistem maupun materi. Hasilnya pun adalah pendidikan hanya sebatas transfer of knowledge. Pendidikan yang seharusnya ialah yang memiliki sebuah karakter yang mendalam, untuk dihayati oleh setiap orang kemudian diaplikasikan dalam kehidupan nyatanya. Sehingga semakin tingginya tingkat pendidikan yang ditempuh, semakin baik pula karakter yang diwujudkannya, karena konsep, sistem maupun materi teraplikasikan dan terintegrasikan dengan arahan yang baik.

Alquran merupakan referensi yang lengkap tentang manusia termasuk pembinaan dan pendidikannya, baik intelektualitas, prilaku, maupun spiritual, Alquran memberikan bimbingan secara komprehensif dan integratif. Di dalamnya terdapat sebuah konsep yang bertujuan untuk memberikan sebuah solusi, diantaranya konsep $\bar{u} l \bar{u} l$ 'ilmi yang merupakan salah satu upaya untuk mengatasi berbagai problematika yang ada. Hal tersebut tergambar dari tafsīr atau makna kata $\bar{u} l \bar{u} l$ 'ilmi dalam Alquran yang tentunya sangat memungkinkan dikembangkan serta diterapkan dalam konsep pendidikan. Úlūl ilmi yang memiliki sebuah pengertian orang yang berilmu, tentunya memiliki sebuah karakteristik tersendiri apabila dikembangkan serta digali melalui berbagai penafsiran.

Di dalam Islam, orang yang diberikan ilmu pengetahuan seringkali disebut sebagai 'ālim (عالم) atau 'ulamā (علماء). Kata 'ilm ini sebenarnya sudah menjadi sebuah kata dalam bahasa Indonesia, bukan hanya sekedar dalam bahasa Arab, bahkan lebih dari itu tercantum dalam Alquran. Kata 'ilm dengan segala akar kata dan bentuknya mempunyai ciri kejelasan. Hal ini termuat 854 kali di dalam Alquran. Kata dimaksud digunakan dalam arti proses pencapaian pengetahuan dan objek pengetahuan (Fitri, 2013).

Adapun kata $\bar{u} l \bar{u} l$ 'ilmi ini hanya diungkapkan satu kali saja yaitu dalam QS. Alĩ Imrān ayat 18. Di mana ayat ini berkenaan dengan kesaksian para malāikat serta orang-orang yang berilmu bahwasannya tiada Tuhan yang berhak disembah melainkan Allah SWT Yang Maha Adil. Al-Maraghi $\left(1974 \mathrm{a}^{3}\right.$, hlm.17) mengatakan bahwasannya orang yang berilmu ialah orang-orang yang memiliki pembuktian dan mampu menjadikan argumentasinya sebagai 
sandaran orang lain. Kemudian dalam ayat ini terdapat hal yang sangat menarik perhatian kita, yaitu mengenai kedudukan mulia yang diberikan Allah kepada $\bar{u} l \bar{u} l$ 'ilmi, yakni orang-orang yang mempunyai ilmu. Setelah Allah menyatakan kesaksian-Nya yang tertinggi sekali, bahwa tiada Tuhan selain Allah, dan kesaksian itu datang dari Allah sendiri, maka Tuhan pun menyatakan pula bahwa kesaksian tertinggi diberikan oleh malāikat. Kemudian kesaksian diberikan pula oleh orang-orang yang berilmu. Artinya tiap-tiap orang yang berilmu, yaitu orang yang menyediakan akal dan pikirannya untuk menyelidiki keadaan alam ini, baik di bumi ataupun di langit, di laut dan di darat, di binatang, di tumbuh-tumbuhan, niscaya manusia itu akhirnya akan sampai juga kepada keimanan yang lebih kuat kepada Allah SWT (Fitri, 2013).

Dalam kontek pendidikan, Islam lebih menekankan ilmu pengetahuan. Sebagaimana dalam Alquran terdapat banyak makna mengenai orang-orang yang berpengetahuan salah satunya ialah kata "ülūl 'ilmi". Jika kita lihat makna "ūlūl 'ilmi" yakni orang yang memiliki ilmu tentunya akan mengarah kepada ranah pendidikan. Pendidikan dapat dikatakan berhasil jika pendidikan itu mampu merealisasikan tujuannya. Maka dari itu orang yang memiliki karakter " $\bar{l} \bar{u} l$ 'ilmi"-lah yang dapat membantu merealisasikan tujuan akhir pendidikan kita yakni menjadi hamba Allah yang memancarkan akhlakul karimah disepanjang kehidupannya.

\section{METODE}

Studi ini bertujuan untuk memperoleh gambaran mengenai konsep $\bar{u} l \bar{u} l$ 'ilmi dalam Alquran, yang berkaitan dengan makna, karakteritik, peran dan fungsi serta implikasi terhadap teori pendidikan Islam. Studi ini dilakukan untuk menyelidiki dan menggali ayat Alquran tentang $\bar{u} l \bar{u} l$ 'ilmi berdasarkan tinjauan beberapa ahli tafsīr dalam kitab Mu'tabaroћ. Desain penelitian ini menggunakan pendekatan kualitatif. Hal tersebut sesuai dengan yang dikemukakan Nana Syaodih dalam bukunya Metode Penelitian Pendidikan (2012, hlm. 60) bahwa "Penelitian kualitatif adalah suatu penelitian yang ditujukan untuk mendeskripsikan dan menganalisis fenomena, peristiwa, aktivitas sosial, sikap, kepercayan, persepsi, pemikiran orang secara individual maupun kelompok".

Metode yang dipergunakan dalam penelitian ini adalah metode penelitian non-interaktif, karena tidak mengumpulkan data dari hasil interaksi dengan manusia. Penelitian noninteraktif itu sendiri disebut juga dengan penelitian analitis, mengadakan pengkajian berdasarkan analisis dokumen. Peneliti menghimpun, mengidentifikasi, menganalisis, dan mengadakan sintesis data, untuk kemudian memberikan interpretasi terhadap konsep $\bar{u} l \bar{u} l$ 'ilmi. Hal ini sesuai dengan apa yang telah dikemukakan Sukmadinata di dalam bukunya yang mengatakan bahwa,

Analisis dokumen merupakan tahapan menghimpun, mengidentifikasi, menganalisis, dan mengadakan sintesis data, untuk kemudian memberikan interpretasi terhadap konsep, kebijakan, peristiwa yang secara langsung atau tidak langsung dapat diamati (Sukmadinata, 2012, hlm. 65).

Dalam penafsiran penelitian ini, secara prosedural metode tafsīr yang digunakan adalah metode tahlīlī (analisis) dan metode muqaran (perbandingan). Metode yang utama digunakan ialah metode tahlīlī (analisis), metode muqaran (perbandingan) digunakan sebagai alat bantu. Dalam penelitian kualitatif yang menjadi instrumen atau alat penelitian adalah peneliti itu sendiri. Penelitian kualitatif sebagai human instrument, 
berfungsi menetapkan fokus penelitian, memilih informan sebagai sumber data, melakukan pengumpulan data, menilai kualitas data, analisis data, menafsirkan data dan membuat kesimpulan atas temuannya. Dengan kata lain peneliti merupakan instrumen kunci dalam penelitian kualitatif (Sugiyono, 2011, hlm. 305-306).

Analisis data dalam penelitian ini menggunakan analisis konten. Analisis konten yang dimaksud dalam penelitian ini adalah menganalisis isi makna kandungan Alquran. Analisis ini berusaha menguraikan serta menjawab rumusan masalah menjadi nampak jelas dan bermakna. Langkah-langkah analisis yang dilakukan dalam penelitian ini berdasarkan langkahlangkah analisis data menurut Sugiyono (2011, hlm. 247-252) yaitu sebagai berikut: (a) Data Reduction (Reduksi Data): merangkum, memilih hal-hal yang pokok, dan memfokuskan data pada hal-hal yang penting. (b) Data Display (Penyajian Data) : dalam bentuk uraian, kemudian tabel dan bagan, agar mempermudah pembaca untuk memahami isi dari kajian makna pernafsiran ayat tersebut. (c) Penarikan kesimpulan (Conclusion Drawing / Verification) : menarik kesimpulan mengenai konsep $\bar{u} l \bar{u} l$ 'ilmi dalam Alquran dengan memberikan kejelasan atas gambaran mengenai makna, karakter, peran dan fungsi serta implikasi edukatif.

\section{HASIL DAN PEMBAHASAN \\ 1. Makna $\bar{U} l \bar{u} l$ 'ilmi}

Berdasarkan hasil temuan dalam Tafsīr Mu'tabaroh, Ūlūl 'ilmi (orang yang berilmu) ialah para utusan Nabi, baik dari kalangan Muhajirin ataupun kalangan Anșor, yang memiliki akal yang tajam serta hatinya teguh beraqidah. Aqidah kuat yang terbentuk dalam dirinya dapat meningkatkan rasa takut kepada Allah. Sehingga, pengalaman ruhani ini mampu mencapai makrifat. Ketajaman akalnya mampu membuktikan realitas yang ada, berdasar pada dalil dan hujjah. Sehingga, ilmu ini mampu memberikan pengaruh yang hidup, karena amal sholeh bukan sebatas membilang tasbih, namun mengintegrasikan ilmu dan iman untuk membentuk amal sholeh secara keseluruhan.

Makna Ūlūl 'ilmi ini, memiliki kesamaan makna dengan $\bar{U} l \bar{u} l$ Albab dan Ulin Nuha yang terdapat dalam Alquran. Ketiga redaksi kata ini, memiliki kecenderungan yang sama dalam mempergunakan akalnya. Alquran menjunjung tinggi kedudukan akal, sebab akal-lah yang membedakan manusia dengan yang lain. Karenanya, manusia memperoleh kedudukan yang tinggi dengan yang lain, dan sebab dengan akal pula manusia mendapat kedudukan yang rendah dibanding makhluk lain. Dengan akal manusia harus bertanggung jawab atas segala perbuatan yang dilakukannya dan akallah sebagai pegangan Allah dalam menentukan seseorang mendapat pahala ataupun mendapat siksa.

Menurut Saefudin (dalam Ulum, 2011, hlm 35) memberi pengertian mengenai Ūlūl Albab bahwa,

$\bar{U} l \bar{u} l$ Albab adalah pemikir intlektual yang memiliki ketajaman analisis terhadap gejala dan proses alamiyah dengan metode ilmiah induktif dan deduktif, serta intelektual yang membangun kepribadian dengan żikir dalam keadaan dan sarana ilmiah untuk kemaslahatan dan kebahagiaan seluruh umat manusia. Ūlül Albab adalah intlektual muslim yang tangguh yang tidak hanya memiliki ketajaman analisis obyektif, tetapi juga subyektif.

Adapun mengenai pengertian Ulin nuha, ada sebagian para ahli yang mengatakan bahwa ini merupakan sebutan untuk Ülūl Albab, yakni dalam tafsīr Al-Azhar dikatakan bahwa yang dimaksud dengan Ulin nuha ialah 
seseorang yang memiliki fikiran dan akal, sehingga akal tersebut dapat mencegah dirinya dari perbuatan yang tidak baik (Ulum, 2011, hlm. 36). Hanya saja kata Ulin nuha dalam Alquran terungkap sebanyak dua kali. Banyak dari para ahli mengatakan bahwa kata Ūlül Albab memiliki makna yang lebih dalam. Begitu pun dengan $\bar{U} l \bar{u} l$ 'ilmi yang terlihat memiliki makna yang dalam pula, meski hanya terungkap satu kali di dalam Alquran. Hal tersebut dapat terlihat pada kata "syahida" sebagai pengawal surah tersebut.

Berdasarkan pemaparan di atas, kata Ūlūl 'ilmi, Ūlūl albab, dan Ulin nuha dalam Alquran, selain terdapat persamaan dalam mempergunakan akalnya, masing-masing memiliki sisi pandangan yang berbeda, dan biasanya perbedaannya terlihat pada konteks ayat yang menentukan tempat kata itu berada. Walau demikian, redaksi kata tersebut saling berkaitan. Kata Ūlūl 'ilmi, Ūlūl albab, dan Ulin nuha ini menggambarkan bahwa konsep akal dalam Alquran tidak semata-mata dalam alam fikir saja, melaikan keterkaitan qalbu di dalamnya. Qalbu yang sehat nan hidup, akan berujung pada kemaslahatan, karena inilah sejatinya Alquran yang selalu menuntun umatnya menuju kemaslahatan, baik dalam orientasi duniawi maupun orientasi ukhrawi.

Adapun perbandingan antara kata Ūlūl 'ilmi, Ūlūl albab, dan Ulin nuha dalam Alquran dapat divisualisasikan dalam bentuk tabel sebagai berikut:
Tabel Perbandingan Kata Ūlūl 'ilmi, Ùlūl albab, dan Ulin nuha

\begin{tabular}{|l|l|l|}
\hline $\begin{array}{c}\text { Redaksi } \\
\text { Kata }\end{array}$ & Persamaan & Perbedaan \\
\hline Ülül 'ilmi & $\begin{array}{l}\text { Memperguna } \\
\text { kan akal }\end{array}$ & $\begin{array}{l}\text { Menanamkan } \\
\text { aqidah yang } \\
\text { kuat }\end{array}$ \\
\hline $\begin{array}{l}\text { Ulül } \\
\text { albab }\end{array}$ & $\begin{array}{l}\text { Memperguna } \\
\text { kan akal }\end{array}$ & $\begin{array}{l}\text { Menanamkan } \\
\text { żikir dan fikir }\end{array}$ \\
\hline $\begin{array}{l}\text { Ulin } \\
\text { nuha }\end{array}$ & $\begin{array}{l}\text { Memperguna } \\
\text { kan akal }\end{array}$ & $\begin{array}{l}\text { Menanamkan } \\
\text { akhlakul } \\
\text { karimah }\end{array}$ \\
\hline
\end{tabular}

Berdasarkan tabel tersebut, terlihat bahwa konsep Ūlūl 'ilmi, $\bar{U} l \bar{u} l$ albab, dan Ulin nuha dalam Alquran saling berkaitan. Żikir, sebagai bentuk ibadah merupakan aktualisasi dari penanaman aqidah yang kuat. Begitu pun dengan akhlak, aktualisasi dari bentuk ibadah serta żikir ini yang akan menunjukan kesempurnaan akhlak di hadapan-Nya. Konsep akal dalam Alquran secara tidak langsung menuntut kita untuk membina diri dalam setiap aspek kehidupan, baik yang berkaitan dengan aspek aqidah, ibadah maupun akhlak. Keterpaduan tiga aspek tersebutlah yang harus dipupuk, dirawat serta dibina oleh genarasi umat Islam. Dengan penanaman aqidah yang kuat dapat menumbuhkan ibadah yang sehat, serta menghasilkan buah akhlak yang baik.

Menjadi orang yang berilmu tentu memerlukan proses berfikir, itulah sebabnya redaksi kata Ūlūl Albab memiliki makna yang banyak, yang terungkap sebanyak 16 kali di dalam Alquran, yang menerangkan berbagai keterangan agar manusia senantiasa menggunakan akalnya dalam proses berfikir. Sehingga dengan akal yang dipergunakannya dapat mengambil setiap pelajaran yang Allah berikan dan berujung kepada penguatan aqidah dan ibadah kepada-Nya. Hal ini termaktub dalam firman-Nya: 


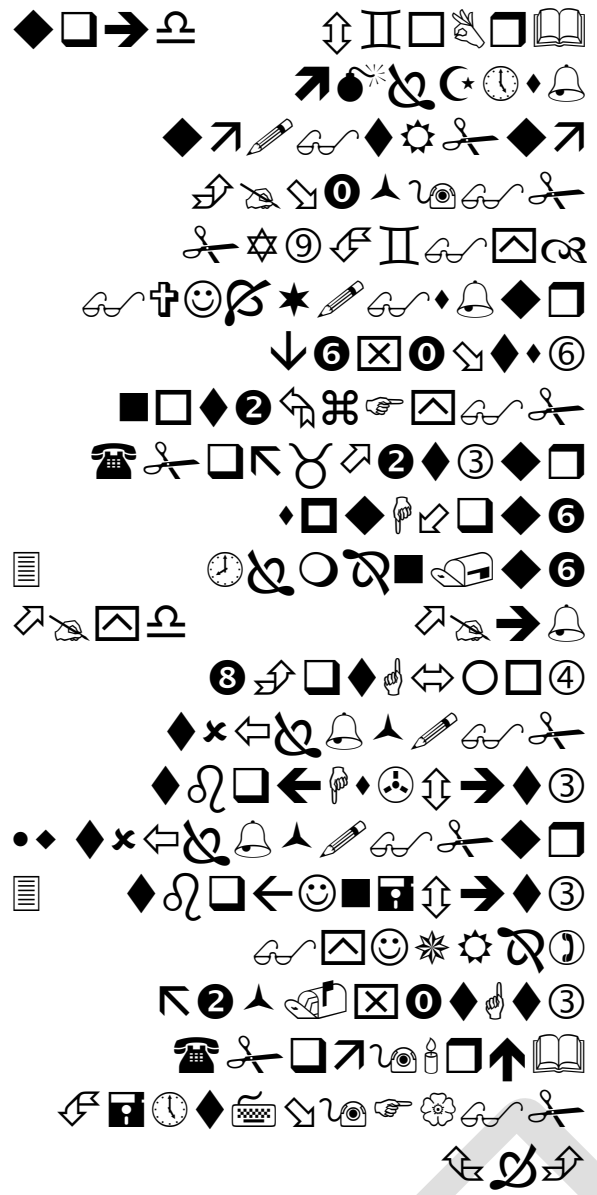

(Apakah kamu Hai orang musyrik yang lebih beruntung) ataukah orang yang beribadat di waktu-waktu malam dengan sujud dan berdiri, sedang ia takut kepada (azab) akhirat dan mengharapkan rahmat Tuhannya? Katakanlah: "Adakah sama orang-orang yang mengetahui dengan orang-orang yang tidak mengetahui?" Sesungguhnya orang yang berakAllah yang dapat menerima pelajaran (Az-Zumar [39]:9).

Ayat tersebut mengindikasikan adanya persamaan karakteristik antara konsep Ülūl 'ilmi dan Ülūl Albab dalam Alquran, yakni memiliki rasa takut kepada Allah SWT sebagai implementasi penanaman aqidah yang kuat yang dibangun dalam proses keilmuan.

Ūlūl 'ilmi terlahir bukan tanpa perjuangan, namun mereka terlahir dengan penuh perjuangan. Oleh karenanya, dalam perjuangan tersebut ada sebuah proses yang harus dilalui untuk memiliki sebuah ilmu. Dalam kajian teori, banyak para ahli yang mengungkapkan pengertian tentang ilmu, penulis mengambil kesimpulan berdasarkan pandangan para ahli tersebut, bahwa ilmu merupakan sebuah pengetahuan yang disusun secara bersistem yang memberikan penjelasan untuk memperoleh pemahamman secara rasional, logis, dan empiris akan suatu objek yang di dapat dengan metode keilmuan, sehingga dengan adanya ilmu dapat menghilangkan kebodohan dan mendatangkan kebenaran yang objektif. Bentukan pengetahuan tersebut ada dalam pikiran manusia, itu artinya manusia merupakan akar dari pembentukan ilmu pengetahuan.

Dalam teori pula, dijelaskan bahwa ilmu tidak semata-mata di dapat dengan begitu saja. Pada dasarnya, ilmu pengetahuan itu datangnya dari Allah. Ilmu diperoleh dengan berbagai macam cara, baik melalui akal fikiran maupun pengetahuan yang tertangkap oleh pancaindra dalam segala aktifitas manusia. Sebagaimana menurut AlFarabi (dalam Muliawan, 2005, hlm. 28) manusia memperoleh pengetahuan tentang sesuatu melalui daya berfikir, daya menghayal, dan daya mengindra.

Di dalam ajaran Islam ada dua jalan untuk memperoleh ilmu pengetahuan yaitu melalui akal, dan wahyu. Shihab (1999, hlm. 434) telah menjabarkan mengenai cara memperoleh ilmu ini, yakni melalui (1) 'ilmu kasby (ilmu yang diperoleh dengan cara usaha manusia), (2) 'ilm laduni (ilmu yang diperoleh tanpa upaya manusia). Cara pertama adalah mengajar dengan alat atau atas dasar usaha manusia sedangkan cara kedua adalah mengajar tanpa alat atau tanpa usaha manusia. Walaupun berbeda namun pada hakikatnya sama bersumber dari Allah SWT.

Berdasarkan pemaran tersebut, $\bar{U} l \bar{l} l$ 'ilmi termasuk ke dalam kategori 'ilmu kasby. Oleh karennya, untuk melahirkan sosok $\bar{U} l \bar{u} l$ ilmi harus 
menjalani beberapa proses, dengan memberdayakan pendengaran, penglihatan, akal serta hati kita untuk digunakan dengan sebaik mungkin agar dapat memperoleh kebenaran yang objektif. Sebagaimana Allah berfirman :

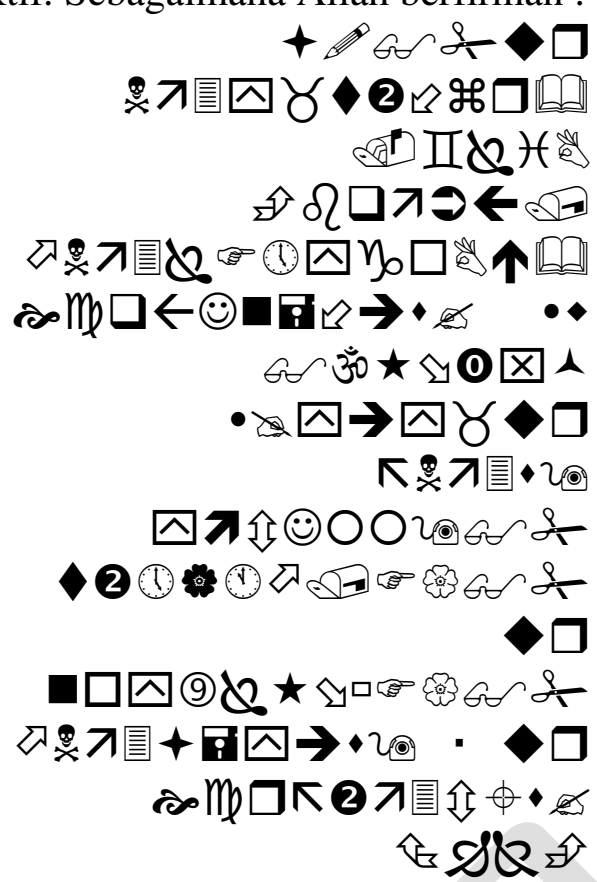

Dan Allah mengeluarkan kamu dari perut ibumu dalam Keadaan tidak mengetahui sesuatupun, dan Dia memberi kamu pendengaran, penglihatan dan hati, agar kamu bersyukur ( QS. An-Nahl [17]: 78).

Oleh karena itu, cara dan sarana yang digunakan untuk meraih pengetahuan tidak hanya sebatas pada pancaindra semata, melainkan membutuhkan hati atau juga melalui tazkiyat al-nafs dan usaha Ilāhiyah (Nurbaethy, 2012, hlm. 169). Lebih lanjut, dalam jurnalnya Nurbaethy (2012, hlm 169) dijelaskan bahwa usaha Ilāhiyyah harus dilakukan dengan proses yang timbul dalam diri, ketika pancaindra mulai melemah, pada saat bersamaan akan muncul daya hati dan akal yang menyebabkan cahaya Ilāhi memenuhi alam akal dan pada akhirnya menghasilkan ma'rifatullāh. Usaha tersebut kerap disebut sebagai riyadah dan mujahadah. Usaha ini, diungkapkan dalam Alquran, sebagai seruan untuk bertaqwa kepada Allah. Seseorang yang membawa ketaqwaan inilah yang akan Allah anugrahkan ilmu, sebab Allah-lah yang memilki otoritas atas segala ilmu.

Berbicara mengenai makna Ūlūl 'ilmi, banyak para mufasir yang menyandingkannya dengan makna ulama. Makna $\bar{U} l \bar{u} l$ 'ilmi yang diperjelas dengan makna ulama ini memiliki makna yang dalam. Ûlūl 'ilmi bukan hanya orang yang memiliki ilmu, akan tetapi kunci yang mendasari orang yang berilmu ini ialah orang yang beraqidah kuat. Aqidah kuat yang terbentuk dalam dirinya dapat meningkatkan rasa takut kepada Allah agar dapat membentuk pribadi yang bertaqwa. Sebagaimana kata "syahada" dalam QS. Alī -Imrān [3]: 18 menjadi sebab seseorang memiliki rasa khasyyah yang dijelaskan dalam QS. Fațir [35]: 28.

Pendapat yang mengatakan bahwa yang dimaksud dengan "ulama" pada ayat ini adalah "yang berpengetahuan agama" sebagaimana yang telah dikatakan oleh Țabațaba'i, bila ditinjau dari segi penggunaan bahasa Arab tidaklah mutlak demikian. Siapa pun yang memiliki pengetahuan, dan dalam disiplin apa pun pengetahuan itu, maka ia dapat dimaknai 'alim. Dari konteks ayat ini pun, kita dapat memperoleh kesan bahwa ilmu yang disandang oleh ulama itu adalah ilmu yang berkaitan dengan fenomena alam (Shihab, 2002 $\mathrm{c}^{11}$, hlm. 62).

Suatu riwayat yang dibawakan dari Sufyan Saur, menjelaskan bahwa ulama itu ada tiga macam; (1) Alim yang mengenal Allah dan mengenal perintah Allah. (2) Alim yang mengenal Allah tetapi tidak mengenal perintah Allah dan (3) Alim yang mengenal perintah tetapi tidak mengenal Allah. Adapun Alim yang mengenal Allah dan perintah-Nya ialah yang takut kepada Allah dan mengenal batas-batas dan perintah serta larangan. Alim yang mengenal Allah tetapi tidak mengenal perintah-Nya ialah yang takut kepada Allah tetapi tidak melaksakana perintah 
karena tidak tahu. Sedangkan Alim yang mengenal perintah Allah dan tidak mengenal Allah ialah yang sangat tahu batas-batas dan perintah Allah tetapi tidak ada rasa takut kepada Allah. Disini terlihat jelas bahwa jangkauan ulama itu amatlah luas (Hamka, 1988, hlm. 246).

Adapun dalam riwayat tafsīr lainnya, dikatakan bahwa ulama adalah orang-orang yang berilmu tentang Allah dan tentang syariah. Dan sesuai dengan ukuran keilmuan dalam hal itu akan menguatkan rasa takut. Adapun orang yang berilmu yang tidak berkaitan dengan Allah serta ganjaran dan hukumannya dengan pengetahuan yang semestinya. Maka bukanlah ilmu yang mendekatkan ketakutan kepada Allah. Hal itu karena orang yang berilmu tentang syariat tidak akan mencampuradukkan hakikat nama-nama yang bersifat syar'i maka dia akan memahami kedudukannya dengan pemahaman yang benar, dan menjaganya dalam kedudukannya, dan akan mengetahui akibat yang baik dan akibat yang buruk. Maka dia akan melaksanakan atau meninggalkan perbuatan-perbuatan apa yang diinginkan oleh Allah, dan dituju oleh syariatNya (Asyur, 1984c $\mathrm{c}^{22}$, hlm. 305).

Berdasarkan uraian tersebut, dapat dipahami bahwa $\bar{U} l \bar{u} l$ 'ilmi merupakan seseorang yang memiliki ilmu berdasarkan realitas, berwawasan luas, kecerdasannya mampu mencapai makrifat, dan hatinya teguh bertauhid karena memiliki tingkatan khasyyah seperti para ulama. Namun ilmu yang dimilikinya tidak sebatas ilmu agama saja, melaikan ilmu rasional serta ilmu empiric lainnya yang dapat mengantarkan keteguhan tauhid di dalam hatinya.

\section{Karakteristik $\bar{U} l \bar{u} l$ 'ilmi}

Berdasarkan hasil temuan, $\bar{U} l \bar{u} l$ 'ilmi memiliki karakteristik tersendiri.
Untuk menjadi sosok Ūlūl 'ilmi (orang yang berilmu), tentu harus memiliki ilmunya terlebih dahulu. Berkaitan dengan ilmu ini, dalam teori telah dipaparkan berbagai karakter ilmu yang telah dikemukakan oleh para ahli. Pada dasarnya ilmu dalam ajaran Islam bercorak Ilāhiyyah. Oleh karenanya, ilmu dalam Islam tidak dapat diceraipisahkan dengan iman. Supadi (2011, hlm. 23) mengungkapkan bahwa, Ilmu memiliki karakteristik tertentu yaitu hasil pemahaman manusia yang disusun dalam suatu sistem mengenai kenyataan, stuktur, pembagian, bagianbagian, dan ukuran tentang hal ikhwal yang diselidiki (objek) sejauh yang dapat dijangkau daya akal manusia dengan melalui pengujian secara empiric, riset, dan eksperimen. Singkatnya, dapat dikatakan bahwa ilmu memiliki ciri-ciri rasional, komulatif, objektif, dan universal.

Dengan demikian, dikatakan sebagai orang yang berilmu harus memiliki kualitas ilmu yang baik dan benar sesuai dengan karakter ilmu yang telah dikemukakan di atas. Berkaitan dengan karakteristik Ūlūl 'ilmi, yang dibicarakan dalam Alquran ialah seseorang yang memiliki kualitas ilmu yang memadai, memiliki keterampilan serta pendalaman yang mumpuni baik dalam aspek aqidah, ibadah maupun akhlak. Memiliki aqidah yang kuat, akan mengantarkan iman yang mantap, melahirkan ketajaman spiritual serta tabi'at yang lurus untuk menularkan energi positif serta memelihara wasiat untuk menunaikan segala bentuk perintah-Nya. Berbagai sikap yang harus tercermin dalam sosok Ûlūl 'ilmi diantaranya ialah; sikap adil, bijaksana, sikap terbuka, lapang dada, budi bahasa yang baik, tawadhu, zuhud, wara', ikhlas, taat, syukur, rasa cinta dan khasyyah, serta istiqomah. Kesempurnaan sikap tersebut akan mewarnai ilmu dengan nilai spiritual yang kuat. 
Berbagai sikap yang telah dipaparkan di atas, dapat terwujud jika kita sebagai generasi Ūlūl 'ilmi mampu menjaga, merawat serta mencusikan hati terlebih dulu. Dengan demikian, ilmu yang dimiliki oleh Ûlūl 'ilmi ini tidak hanya berorientasi pada duniawi, melainkan berorientasi ukhrawi.

Dari sekian sikap yang harus dimiliki oleh generasi Ūlūl 'ilmi di atas, terlihat jelas bahwa karaktereristik yang dimiliki oleh $\bar{U} l \bar{u} l$ 'ilmi bukan hanya pada ranah kognitif saja, melainkan terdapat ranah lainnya seperti ranah afektif, ranah psikomotorik, ranah sosial, ranah etika dan ranah spiritual. Pengklasifikasian karakteristik $\bar{U} l \bar{u} l$ 'ilmi ini dapat divisualisasikan dalam bentuk tabel. (lihat tabel klasisfikasi karakter Ūlūl 'ilmi)

Dari tabel tersebut dapat disimpulkan bahwa karakteristik Ūlū 'ilmi memiliki ciri khas yang berbeda dengan yang lain, yakni memiliki nuansa Ilāhiyyah, spiritual dan bathiniyyah. Karakteristik ini mencangkup pada enam ranah, yakni ranah kognitif, ranah afektif, ranah psikomotorik, ranah sosial, ranah etika dan ranah spiritual. Namun, yang menjadi kunci utama karakteristik Ūlül 'ilmi ialah menghasilkan khasyyah yang kuat terhadap Rabb-nya, sebagai sebab ilmu yang dimilikinya. Untuk pencapaian sikap tersebut, seseorang dapat melakukan beberapa langkah berikut untuk mencapai khasyyah yang kuat, diantanya ialah (1) Mujāhadah (2) Muhāsabah (3) Murāqobah (4) Muhabbah (5) Ma'rifatullāh. Kesungguhan dalam mendalami ilmu, menjadikan seseorang pandai bertindak dalam menentukan langkah dengan berbagai pertimbangan menuju kemaslahatan. Kemaslahatan inilah yang akan mengantarkan seorang hamba lebih dekat dengan Rabb-nya, hingga rasa cintanya tumbuh begitu kuat. Kedekatannya dapat mencapai ma'rifatullāh. Inilah tujuan akhir dari
Ūlùl 'ilmi, dengan berbagai macam karakter yang ada dalam dirinya mampu berujung Lillāh.

\section{Peran dan Fungsi $\bar{U} l \bar{u} l$ 'ilmi}

Manusia diciptakan oleh Allah dengan bentuk yang sebaik-baiknya. Manusia dikarunia berupa akal pikiran sebagai bekal dalam mengarungi kehidupan. Oleh sebab itu, manusia dan ilmu memiliki hubungan yang sangat erat. Manusia tidak akan dapat bertahan hidup tanpa ilmu dan ilmu tidak akan berkembang tanpa peranan manusia. Itu artinya, peran dan fungsi ilmu pengetahuan amatlah penting sebagai bekal dalam mengarungi kehidupan menuju dinamisasi peradaban yang lebih baik. Ilmu berfungsi sebagai sandaran argumentasi dalam bertindak, namun jauh dari pada itu ilmu dapat berfungsi sebagai kunci pembuka amal yang akan mendatangkan kemaslahan. Kemaslahatan itulah yang akan membawa kebersihan hati dan kemulian diri di hadapan Allah SWT. Begitu pun dengan peran dan fungsi Ûlūl 'ilmi (orang yang berilmu) sebagai fasilitator untuk mewujudkan peran dan fungsi ilmu tersebut.

Alquran telah menggambarkan konsep Ūlūl 'ilmi yang berkaitan dengan peran dan fungsi Ûlūl ílmi, diantaranya ialah sebagai berikut:

a. Membina jiwa, akal dan hati.

b. Membina niat agar senantiasa berujung Lillāh.

c. Membina hati agar selalu bertauhid.

d. Memberikan hujjah dan bukti.

e. Menumbuhkan rasa cinta dan khasyah kepada Allah.

f. Menumbuhkan keyakinan dengan tali keimanan.

g. Memelihra wasiat dengan menunaikan perintah-Nya.

h. Mengingatkan dalam berjihad dan berbuat kebaikan.

i. Menegakkan keadilan dan kebenaran. 
j. Mencipatakan keteraturan dan kedamaian.

k. Menjalin silaturahmi yang harmonis.

1. Mengungkapkan rahasia keesaan Allah.

m. Mengungkap realitas kebenaran ilmu.

n. Membina keseimbangan jasmani dan rohani.

o. Membina akhlakul karimah.

p. Memberikan pengaruh positif dan motivasi.

q. Sebagai fasilitator bertaqarub kepada Allah.

r. Sebagai fasilitator untuk meraih kemenangan dunia akhirat.

s. Sebagai fasilitaor untuk meraih rezeki dan rahmat Allah.

t. Sebagai fasilitator untuk mempermudah jalan manusia menuju syurga.

u. Sebagai fasilitator untuk meraih kelapangan dan ketinggian martabat di sisi Allah.

v. Sebagai fasilitator untuk meraih derajat taqwa dan kemuliaan diri di hadapan Allah.

Pemaparan di atas, mengenai peran dan fungsi Ûlūl 'ilmi dalam konsep Alquran selaras dengan apa yang telah dipaparkan oleh Rizal (2014, hlm. 9) yang mengatakan bahwa peran dan fungsi ilmu ialah untuk meningkatkan spiritual, penataan hidup, pencapaian kebahagian lahir dan batin, serta dinamisasi peradaban. Keselaran peran dan fungsi ilmu dengan peran dan fungsi $\bar{U} l \bar{u} l$ 'ilmi dapat divisualisasikan dalam tabel (lihat tabel keselaran peran dan fungsi ilmu dengan peran dan fungsi Ūlūl 'ilmi).

Dari tabel tersebut dapat diketahui bahwa esensi yang paling utama dari peran dan fungsi Ūlūl ílmi ini adalah membina jiwa, akal dan hati umat manusia menjadi terarah, sehingga terciptanya keseimbangan jasmani dan rohani dalam dirinya. Dengan demikian orang yang berilmu dalam konsep Alquran bukan semata-mata yang memiliki banyak pemikiran, ide serta gagasan. Namun orang yang berilmu harus mampu memberikan pengaruh serta motivasi positif untuk mengarahkan umat menuju pencapaian hakikat Rabb-nya. Inilah fungsi yang utama, seseorang yang bertindak setelah mengetahui ilmunya. Karena inilah hakikat utama ilmu menjadi landasan utama ketika beramal.

\section{Implikasi Edukatif Konsep $\bar{U} l \bar{u} l$ 'ilmi}

a. Pendidik

Berkaitan dengan hal tersebut, sosok Ūlūl 'ilmi yang terungkap dalam Alquran sebagaimana dalam pembahasan konsep Ūlūl 'ilmi ini, pendidik merupakan orang yang berilmu yang harus memiliki kemampuan lebih dalam mengintegrasikan ilmu dan amalnya karena keberadaan iman yang kuat di dalam hatinya, sehingga memiliki pengalaman ruhani yang baik untuk ditularkan kepada anak didiknya. Adapun tugasnya; (1) Seorang pendidik harus mampu menanamkan ketauhidan yang kuat terhadap anak didiknya. (2) Seorang pendidik harus mempu mengarahkan aktifitas spiritual yang baik dan benar. (3) Seorang pendidik harus mampu membina pribadi anak didik menuju tabiat yang lurus, baik itu membina jiwa, akal maupun hati. (4) Seorang pendidik harus mampu memberikan motivasi serta dorongan yang positif terhadap anak didiknya. (5) Seorang pendidik harus mampu memiliki keterampilan untuk membina kesadaran anak didiknya, agar lebih dekat kepada Rabb yang menciptakannya.

Dari sekian tugas pendidik di atas, nampaknya termuat syarat khusus yang harus dimiliki seorang pendidik dalam menjalankan berbagai tugas tersebut, diantaranya (1) Seorang pendidik harus memiliki ilmu yang benar, mapan dan 
sesuai dengan realitas kebenaran berdasar pada Alquran dan as-Sunah. (2) Seorang pendidik harus memiliki pengalaman ruhani yang baik, agar dapat memberikan pengaruh positif terhadap anak didiknya. (3) Seorang pendidik harus memiliki akidah yang benar, ibadah yang sehat, serta tabi'at yang lurus. (4) Seorang pendidik harus memiliki beberapa sikap terpuji yang dapat mengantarkan anak didik menuju ma'rifatullah, diantara sikap tersebut ialah; adil, bijaksana, memiliki himmah yang kuat, sikap terbuka, lapang dada, tutur kata yang baik, tawadhu, ikhlas, zuhud, memiliki rasa cinta dan kasih, serta rasa khasyyah yang dalam terhadap Rabb-nya. Dari sekian sikap tersebut akan nampak pribadi yang berjiwa besar karena hati bertauhid. Inilah sosok pribadi Ūlūl 'ilmi yang harus ada dalam pribadi seorang pendidik yang memiliki tanggungjawab yang besar dalam membangun generasi umat Islam.

Sepadan dengan itu, Moh. Athiyah Al Abrasyi (dalam Ainissyifa, 2014, hlm. 14) mengatakan bahwa seorang pendidik harus memiliki sifatsifat tertentu agar dapat menjalankan tugasnya dengan baik diantaranya ialah; zuhud (tidak mengutamakan materi dan mengajar dengan penuh keikhlasan), memiliki akhlak terpuji untuk diteladani, pemaaf, sanggup menahan diri dari amarah, lapang hati, sabar, mencintai muridnya dengan sepenuh hati, menguasai materi, berpengetahuan luas.

Adapun kedudukan pendidik, yakni sebagai pewaris Nabi. Akan tetapi, bukan saja yang memiliki gelar sebagai ulama atau 'alim, namun generasi $\bar{U} l \bar{u} l$ 'ilmi berkewajiban pula untuk mewariskan seluruh ajaran dengan mengajarkan berbagai macam kebaikan kepada umat. Sebagaimana (Syahidin, 2009, hlm 68) mengatakan bahwa seorang pendidik diharapkan mampu mewariskan nilai-nilai
Ilāhiyyah serta mengikuti jejak Rasūl Allah, karena dalam pelaksanaan tugasnya Rasūl Allah mampu mengembangkan semua aspek kepribadian para sahabat. Dalam konteks pendidikan, beliau bertindak sebagai pendidik yang mampu menghasilkan generasi pilihan sepanjang sejarah peradaban manusia. Pendidikan yang dilakukannya mulai dari proses penyucian jiwa, pikir, dan fisik. Baru kemudian proses ta'lìm, yaitu menyampaikan sejumlah pengetahuan dan syariat Islam.

\section{b. Peserta didik}

Dalam konsep Ūlūl 'ilmi, peserta didik merupakan seseorang yang memiliki akal sehat, yang sedang berjuang menjadi orang yang berilmu diiringi dengan aktualisasi iman dan amal dalam melalui proses pembelajaran. Oleh karenanya, hal tersebut memberi peluang untuk dirinya dalam mewujudkan pribadi yang mandiri dan bertanggungjawab sebagai bekal dalam mengarungi kehidupannya. Sebagaimana dalam UU sisdiknas, pasal 1 ayat 4 dinyatakan bahwa "Peserta didik adalah anggota masyarakat yang berusaha mengembangkan potensi diri melalui proses pembelajaran yang tersedia pada jalur, jenjang, dan jenis pendidikan tertentu" (Umar, 2012, hlm. 94). Peserta didik dalam pendidikan Islam adalah individu yang sedang tumbuh dan berkembang, baik secara fisik, psikologis, sosial, dan religius dalam mengarungi kehidupan di dunia dan di akhirat kelak (Nata, 2010, hlm. 173).

Adapun beberapa syarat yang harus dimiliki peserta didik dalam mewujudkan generasi Ûlūl 'ilmi , diantaranya ialah; (1) Peserta didik harus memberdayakan akal dan hatinya untuk senantiasa berfikir, memahami, serta merenungi berbagai informasi yang tersampaikan. (2) Peserta didik 
harus memiliki motivasi serta dorongan yang kuat untuk belajar. (3) Peserta didik harus memiliki kesadaran yang tinggi dalam membina aqidah yang kuat, ibadah yang sehat serta tabi'at yang lurus. (4) Peserta didik harus tunduk dan patuh terhadap perintah serta nasehat yang diberikan oleh pendidik. Hal ini sepadan dengan pendapat Ali bin Abi Thalib mengenai syarat yang harus ada dalam diri peserta didik, ada enam syarat diantaranya yaitu: kecerdasan, hasrat atau motivasi yang keras, sabar, modal (sarana), petunjuk guru, dan masa yang panjang (kontinu) (Mujib \& Mudzakkir, 2008, hlm. 115).

Apabila syarat tersebut telah terbangun dalam diri peserta didik, maka dengan mudah dapat mewujudkan pribadi Ûlül 'ilmi yang mandiri serta bertanggungjawab. Namun bukan hanya itu saja, pribadi yang diharapkan kelak ialah menumbuhkan sikap terpuji lainnya seperti, adil, bijaksana, taat, sikap terbuka, lapang dada, tutur kata yang baik, tawadhu, ikhlas, zuhud, memiliki rasa cinta dan kasih, serta rasa khasyyah yang dalam terhadap Rabbnya. Dari sekian sikap tersebut akan nampak pribadi yang berjiwa besar karena hati bertauhid. Inilah tugas akhir dari sosok Ûlūl 'ilmi yang diharapkan.

\section{c. Tujuan Pendidikan}

Pendidikan Islam bertujuan untuk menumbuhkan pola kepribadian manusia yang bulat melalui latihan kejiwaan, kecerdasan otak, penalaran, perasaan, dan indra. Pendidikan harus melayani pertumbuhan manusia dalam semua aspeknya, baik spiritual, intelektual, imajinasi, jasmaniah, ilmiah maupun bahasanya (secara perorangan maupun berkelompok). Tujuan akhir dari pendidikan Islam itu terletak dalam realisasi sikap penyerahan diri sepenuhnya kepada Allah (Arifin, 2008, hlm. 29).
Berkaitan dengan hal itu, Ūlūl 'ilmi memiliki tujuan yang sama untuk menunjang ketercapaian tujuan pendidikan Islam tersebut, Ūlūl 'ilmi sebagai generasi orang yang berilmu memiliki sebuah tujuan yakni mengungkap keesaan Allah dengan pembinaan jiwa, akal dan hati menuju pribadi yang mampu menunjukkan prilaku-prilaku yang sesuai dengan $\bar{U} l \bar{u} l$ 'ilmi serta yang utama ialah memiliki khasyyah yang mendalam terhadap $R a b b$-nya karena hati bertauhid dengan keikhlasan dan keistiqamahan di jalanNya.

Adapun jalan yang ditempuh untuk mencapai tujuan tersebut ialah dengan cara; (1) Mujāhadah (kesungguhan untuk mendalami ilmu Allah). (2) Muhāsabah (memperhitungkan ilmu yang didapat, agar seimbang dalam aktualisasi iman dan amal). (3) Murāqabah (mendekatakan diri kepada Allah sebagai bentuk aktualisasi ilmu). (4) Muhabbah (mencintai Allah dengan rasa khasyah dan kagum kepada-Nya). (5) Ma'rifatullāh (mengenal Allah dengan mengungkap keesaan-Nya).

Dengan demikian, pendidikan agama Islam diharapkan menghasilkan manusia yang selalu berupaya menyempurnakan iman, taqwa, dan akhlak, serta aktif membangun peradaban dan keharmonisan kehidupan, khususnya dalam memajukan peradaban bangsa yang bermartabat (Khoirunnisa, 2012, hlm. 149).

\section{d. Peran dan Fungsi Pendidikan}

Pendidikan menurut Islam berfungsi mengubah perkembangan alami menjadi perkembangan terarah dan tertuju. Pendidikan menurut konsepsi Islam bertugas mengubah orientasi alami kehidupan dari duniawi, yang didorong oleh kehendak alami, menjadi berorientasi ukhrawi, yang 
didorong oleh kesadaran kebaikan di dalam dirinya (Rizal, 2014, hlm. 6).

Berkaitan dengan hal tersebut, Ùlūl 'ilmi memiliki peran dan fungsi sebagai fasilitator untuk menunjang ketercapaian tujuan pendidikan. Diantaranya peran dan fungsi pendidikan jika dilihat dari konsep $\bar{U} l \bar{u} l$ 'ilmi ialah;

1. Membina jiwa, akal dan hati.

2. Membina niat agar senantiasa berujung Lillāh.

3. Membina hati agar selalu bertauhid.

4. Memberikan hujjah dan bukti.

5. Menumbuhkan rasa cinta dan khasyah kepada Allah.

6. Menumbuhkan keyakinan dengan tali keimanan.

7. Memelihra wasiat dengan menunaikan perintah-Nya.

8. Mengingatkan dalam berjihad dan berbuat kebaikan.

9. Menegakkan keadilan dan kebenaran.

10. Mencipatakan keteraturan dan kedamaian.

11. Menjalin silaturahmi yang harmonis.

12. Mengungkapkan rahasia keesaan Allah.

13. Mengungkap realitas kebenaran ilmu.

14. Membina keseimbangan jasmani dan rohani.

15. Membina akhlakul karimah.

16. Memberikan pengaruh positif dan motivasi.

17. Sarana bertaqarub kepada Allah.

18. Sarana untuk meraih kemenangan dunia akhirat.

19. Sarana untuk meraih rezeki dan rahmat Allah.

20. Sarana untuk meraih kemudahan jalan manusia menuju syurga.

21. Sarana untuk meraih kelapangan dan ketinggian martabat di sisi Allah.

22. Sarana untuk meraih derajat taqwa dan kemuliaan diri di hadapan Allah.

Peran dan fungsi pendidikan yang

dilihat dari konsep Ūlūl 'ilmi di atas, mampu diarahkan terhadap pembinaan empat kompetensi pendidikan yang diantaranya ialah; spiritual, pengetahuan, sosial dan keterampilan. Namun disini sangat terlihat bahwa keterampilan harus mampu menguasai ranah spiritual, pengetahuan dan sosial (lihat tabel kompetensi pendidikan dalam konsep Ūlūl 'ilmi).

Dari sekian peran dan fungsi tersebut, tolak ukur yang utama ialah meningkatkan kecerdasan sprirtual dan kecerdasan emosional, dengan dua kecerdasan tersebut dapat dengan mudah untuk mewariskan nilai-nilai Ilāhiyyah. Sebagimana menurut Nata (2003, hlm. 52) peran atau fungsi pendidikan ialah sebagai upaya meningkatkan kecerdasan emosional. Dapat disebut demikian, karena di dalam dunia pendidikan khususnya dalam pendidikan Islam diajarkan pengetahuan mengenai bagaimana cara manusia berakhlak. Dengan itu potensi emosional yang ada dalam diri manusia dapat dikembangkan dan diarahkan ke dalam emosi yang positf.

Dengan demikian, dapat disimpulakan bahwa peran dan fungi pendidikan Islam tiada lain ialah untuk mewariskan nilai-nilai Ilāhiyyah dalam diri manusia agar kelak dapat mengantarkan manusia menuju orientasi ukhrawi bukan sekedar orientasi duniawi semata. Dengan pendidikan, upaya peningkatan intelektual, emosional, serta spiritual terarah dengan baik dan benar.

\section{e. Prinsip-prinsip Pendidikan Islam}

Dalam tujuan pendidikan Islam, diperlukan pula prinsip-prinsip guna memastikan tujuan pendidikan tersebut dapat tercapai (Mujib \& Mudzakkir, 2008, hlm. 73). Dalam pembahasan ayat yang telah dikaji dalam penelitian ini, memberikan implikasi terhadap prinsip pendidikan Islam, yakni sebagai berikut:

1) Prinsip Raḥmāniyyah (Kasih Sayang) 
Yang

dimaksud

rahmāniyyaћ sebagai prinsip pembelajaran adalah bahwa kasih sayang seyogyanya menjadi cara pandang dan pola sikap dalam pengembangan seluruh komunikasi dan interaksi dalam pembelajaran (Abdussalam, 2011, hlm. 162-163).

Dalam kajian ayat, yang telah dipaparkan dalam penelitian ini, mengindikasikan adanya karakter positif bagi pendidik, salah satunya ialah memberikan motivasi, dorongan serta pengaruh yang hidup. Pada dasarnya untuk mewujudkan itu semua berawal pada rasa kasih sayang yang terpancar dalam hati sanubari. Sebagaimana Syahidin (2009, hlm.59) mengatakan bahwa konsep ini lahir dari dasar keimanan yang memancarkan perasaan dan motivasi dalam seluruh tindakan pendidikan. Sentuhan kasih sayang yang tulus ditampilkan dalam komunikasi harmonis antara pendidik dan terdidik. Seorang guru dirasakan selalu hadir dalam seluruh konteks kehidupan muridnya.

Rasa kasih sayang ini pun termuat dalam QS. Al-Mujādillah [58]:11 bahwa Allah mengangkat kedudukan orang yang yang berilmu dan memberikan kemulian derajat di hadapan-Nya. Ini merupakan sebuah kabar gembira untuk orang-orang yang beriman, selain untuk menyeru perintah-Nya, Allah menunjukan balasan mulia karena kasih sayang-Nya yang luas terhadap hamba-Nya. Prinsip kasih sayang ini harus terbangun dengan dasar keimanan. Sebagaimana dalam QS. Alī -Imrān [3]: 18 memberikan seruan untuk orang yang beriman untuk membina hati agar selalu bertauhid.
2) Prinsip Takāmuliyyaћ (integratif)

Berdasarkan kajian ayat, yang telah dipaparkan dalam penelitian ini dijelaskan bahwa ilmu tak kan bermakna jika tak beriringan dengan iman dan amal. Oleh kareannya, iman yang diintegrasikan dengan ilmu akan menjadi butiran amal. Keduanya merupakan sesuatu yang tidak dapat dipisahkan satu sama lainnya untuk menbentuk sebuah amal yang utuh. Hal ini mengindikasikan bahwa dalam proses pendidikan harus memiliki prinsip takāmuliyyah (integratif) artinya tidak ada dikotomi atau pemisahan baik dari segi materi maupun segala hal menyangkut pendidikan itu sendiri. Dalam arti lain proses pendidikan harus memiliki prinsip keterpaduan yang sangat kokoh.

Pemaparan di atas, dipertegas oleh Aam Abdussalam (2011, hlm. 179) bahwa pendidikan dalam pengembangan teori dan praktek pembelajaran dibangun atas prinsip keterpaduan yang sangat kokoh. Keterpaduan tersebut menyangkut pengembangan sumber-sumber belajar, pengalaman belajar maupun pengembangan aspekaspek kepribadian manusia. Adapun pengembangan sumber belajar tidak mengakui adanya dikotomi antara ayat-ayat qawliyyah dengan ayat-ayat kawniyyah. Pengembangan pengalaman belajar tidak mengakui dikotomi antara teori dan praktik, ilmu dan amal, empirik dan intuitif. Pengembangan aspek-aspek kepribadian tidak mengakui adanya dikotomi antara jasadiyyah, 'aqliyyah dan rūhiyyaћ. 
3) Prinsip

Syumūliyyaћ

(komprehensif, universal)

Di dalam kajian ayat, yang telah dipaparkan dalam penelitian ini dijelaskan bahwa keseluruhan ilmu yang dipelajari harus berujung mengantarkan diri mencapai makrfatullah. Itu artinya, dalam proses pendidikan berbagai materi yang diajarkan harus mampu berujung ma'rifatullāh, menumbuhkan rasa kagum dan khayyah karena hati tertuntun untuk mengAgungkanNya.

Sebagaimana dalam kajian teori dijelaskan bahwa yang dimaksud dengan prinsip syumūliyya $\hbar$ adalah pembelajaran meliputi seluruh entitas dan dimensi kehidupan (Abdussalam, hlm.196). Prinsip syumūliyyaћ menetapkan segala sesuatu, baik yang nampak atau yang abstrak, sebagai objek ilmu dan pembelajaran yang sah (Abdussalam, 2011, hlm. 201).

4) Prinsip (keseimbangan)

Prinsip Tawāzuniyyah adalah prinsip keseimbangan dimana proses pendidikan dituntut adanya keseimbangan dan pengalaman belajar, yakni pengalaman belajar yang tidak hanya memuaskan indra (pengamatan empirik), melainkan harus mampu memuaskan akal atau nalar, emosi dan hati atau intuisi. Tanpa memuaskan aspekaspek tersebut, maka pembelajaran akan mengakibatkan ketimpangan atau kehilangan keseimbangan (Abdussalam, 2011, hlm. 210).

Dalam penelitian ini, dijelaskan bahwa kekuatan aqidah yang terbangun dalam diri akan membawa keterarahan aktifitas spiritual dalam membina tabi'at yang lurus. Dengan demikian, berawal dari hati yang bertauhid inilah yang akan dapat menciptakan keseimbangan diri, baik itu secara jasmani maupun rohani.

5) Prinsip Rabbāniyyaћ (Ketuhanan) Prinsip Rabbāniyyah berarti pendidikan harus menempatkan Rabb atau nilai-nilai-Nya sebagai rujukan dan tujuan utama. Dengan prinsip ini, pembelajaran hendaknya diarahkan pula untuk melihat dan menghayati kehadiran serta keterlibatan Rabb dalam seluruh fenomena, khususnya fenomena atau yang materi yang dipelajari (Abdussalam, 2011, hlm. 230). Sebagaimana yang telah dipaparkan dalam kajian ayat, bahwa QS. Alī -Imrān [3]: 18 memberikan sebuah gambaran khusus bahwa kata "syahada" (persaksian kalimah lā ilāha illa Allah) menjadi pondasi utama membangun diri untuk mencapai ma'rifatullāh. Dengan demikian, dalam proses pendidikan pun prinsip Rabbāniyyah harus mampu ditanamkan dengan baik melalui penanaman nilai-nilai Ilāhiyyah, agar hati selalu bertauhid untuk mencapai ma'rifatullāh.

\section{5) Materi dalam Proses Pendidikan Islam}

Dalam penelitian ini tergambar beberapa materi yang harus ada dalam proses pendidikan Islam, seperti halnya materi yang berkaitan dengan agama, rasional, empiric serta ilmu terapan. Namun, esensi yang paling penting dalam konsep Ūlūl 'ilmi ialah materi yang berkaitan dengan agama, yang dimana disana terdapat kesatuan materi antara ilmu, iman, amal dan akhlak. Sehingga materi tersebut jika dikembangkan mengandung nilai-nilai 
Ilāhiyyah. Dengan adanya empat aspek tersebut, ilmu apapun yang dipelajari akan mendatangkan manfaat karena ada nilai-nilai Ilāhiyyah di dalamnya, sehingga hal ini akan meminimalisir faham sekularisme yang kerap menyebar di tanah air ini. Nilai-nilai Ilähiyyah ini akan membantu menguatkan hati seseorang agar terus bertauhid dan mencapai ma'rifatullāh.

Hal ini selaras dengan Syahidin (2009, hlm. 71) yang mengatakan bahwa setidaknya ada empat hal pokok yang perlu dijadikan materi pendidikan dalam usaha membina semua unsur kemanusiaan pada setiap aspek kehidupannya, yaitu iman, ilmu, amal, dan akhlak. Iman merupakan sumber akhlak yang mulia. Akhlak menuntun manusia kepada kebenaran yang merupakan hakikat ilmu, dan ilmu menuntun manusia untuk beramal shaleh.

Dengan demikian, dapat disimpulkan bahwa pendidikan seharusnya tidak ada pemisahan sumber belajar termasuk didalamnya materi. Materi yang bersifat empirik, rasional serta spiritual seharusnya saling melengkapi, yang merupakan satu kesatuan yang harus dipahami untuk memahami hal-hal yang bersifat ilāhiyyah. Dengan kata lain, bahwa untuk menumbuhkan nilai spiritual, kita memerlukan ilmu-ilmu yang bersifat rasional dan empiric, seperti halnya untuk mengenal Allah maka kita membutuhkan hal-hal yang bersifat empirik seperti halnya alam semesta sebagai ciptaan-Nya. Artinya, kita mengenal Allah melalui ciptaan-Nya sehingga tumbuhlah hati yang senantiasa bertauhid kepada-Nya dengan mengAgungkan-Nya.

\section{6) Metode dalam Proses Pendidikan Islam}

Dalam proses pendidikan Islam, metode mempunyai kedudukan yang sangat penting dalam upaya pencapaian tujuan, karena ia menjadi sarana dalam menyampaikan materi pelajaran yang tersusun dari kurikulum. Tanpa metode suatu materi pelajaran tidak dapat berproses secara efisien dan efektif dalam kegiatan belajar mengajar menuju tujuan pendidikan (Arifin, 2008, hlm. 144).

Dalam penelitian ini, ditemukan beberapa metode pendidikan Islam dalam ayat- ayat yang berkaitan dengan konsep Ūlùl 'ilmi. Metode tersebut diantaranya adalah metode Uswāh

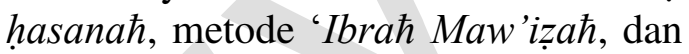
metode Targib.

\section{(a) Metode Uswāh hasanaћ}

Metode uswāh hasanah merupakan metode yang digunakan dengan cara memberikan contoh teladan yang baik, yang tidak hanya memberi di dalam kelas, tetapi juga dalam kehidupan sehari-hari (Mujib \& Mudzakkir, 2008, hlm. 197).

Dalam penelitian ini, ayat yang mengandung metode uswāh hasanaћ adalah QS. Alī -Imrān [3]:18 dan QS. Faṭir [35]:28 sebagai berikut:

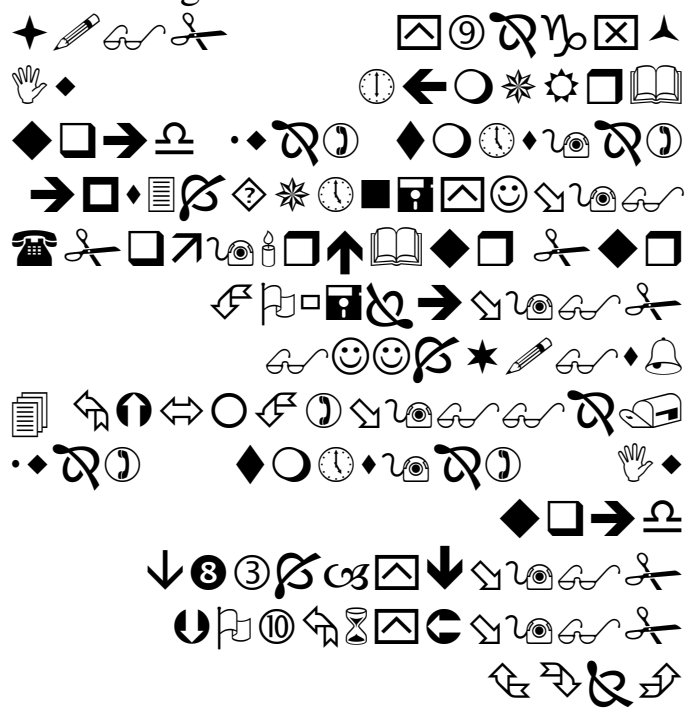

Allah menyatakan bahwasanya tidak ada Tuhan melainkan Dia (yang berhak disembah), yang menegakkan keadilan. Para Malaikat dan orang-orang yang 
berilmu (juga menyatakan yang demikian itu). tak ada Tuhan melainkan Dia (yang berhak disembah), yang Maha Perkasa lagi Maha Bijaksana. (QS. Alī -Imrān [3]: 18)

Dalam ayat ini mengandung persaksian yang amat dalam selain Allah, para Malaikat serta orang yang berilmu pun melakukan persaksian tersebut. Hal ini merupakan sebuah alasan mengapa ayat ini termasuk ke dalam metode uswāh hasanaћ, karena tiga persaksian ini memberikan contoh agar banyak orang yang menggerakkan hatinya untuk memberikan persaksian yang agung. Dengan persaksian redaksi kata "Là ilāha illa Allah" yang dihayati dapat menggerakkan hati agar selalu bertauhid.

Dalam kitab tafsīr "At-Tarhrir Wa Tanwir" ditegaskan tiga persaksian yang dimaksud ini ialah (1) Allah; kesaksian Allah membenarkan keesanNya. (2) Malaikat; membenarkan dan menyampaikan kepada para Rasul. (3) Orang yang berilmu; membenarkan dengan hujjah dan dalil (Asyur, 1984a ${ }^{3}$, hlm. 186).

Berbicara mengenai persaksian Allah, mengapa kesaksian Allah ini perlu disampaikan langsung oleh-Nya? Al-Biqa'i mengemukakan dalam tafsīr Al-Miṣbāḥ , bahwa kesaksian dari yanng perkasa biasanya dilakukan bila dia melihat bahwa ada pengikutnya yang bermalas-malasan melaksanakan perintah, atau mengabaikan tugas-tugsa mereka. Dengan kesaksian itu, Allah mengingatkan mereka bahwa situasi telah mencapai satu kondisi yang tidak dapat dibiarkan. Nah, serupa itulah yang Allah lakukan menghadapi sekian banyak hamba-hambaNya yang mengabaikan perintah dan melalaikan tugas (Shihab, 2002a ${ }^{1}$, hlm. 37).

Berdasarkan penuturan Shihab di atas, terlihat bahwa manusia cenderung memiliki sifat negatif. Banyak manusia di kehidupan ini yang melalaikan tugas serta perintah-Nya. Itulah sebabnya mengapa persaksian ini begitu kuat. Allah membenarkan mengenai keesaanNya, Malaikat membenarkan melalui ketaatan-Nya. Dan kita sebagai generasi orang yang berilmu harus mampu membenarkan syahadah yang agung ini melalui hujjah dan bukti yang diselidiki oleh akal yang kuat dan sehat melalui perenungan yang berakar dari hati. Inilah sebuah keteladan yang harus kembali diingat dan diikuti, untuk menunaikan seluruh perintah-Nya dengan sebaik mungkin.

Adapun redaksi ayat lainnya,

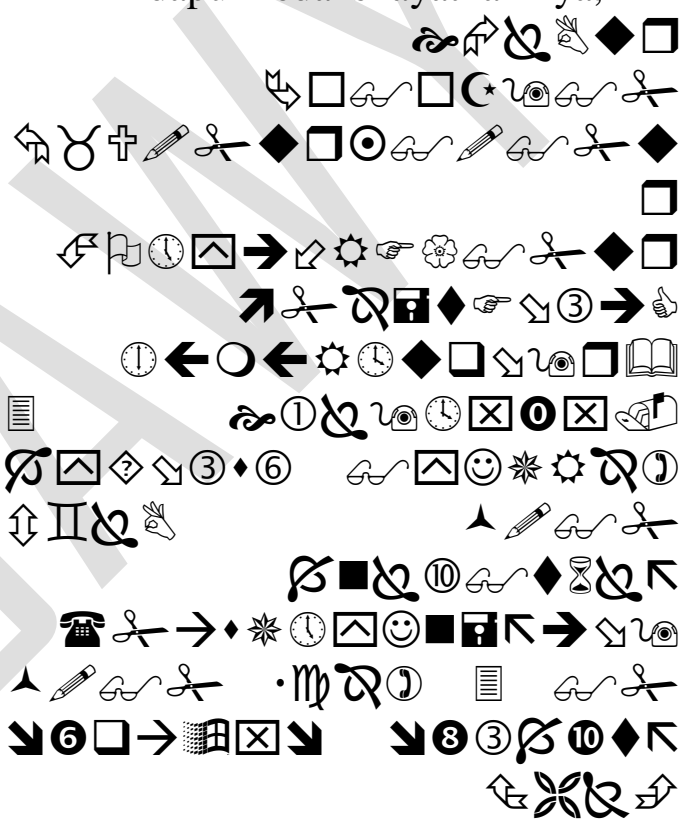

Dan demikian (pula) di antara manusia, binatang-binatang melata dan binatangbinatang ternak ada yang bermacammacam warnanya (dan jenisnya). Sesungguhnya yang takut kepada Allah di antara hamba-hamba-Nya, hanyalah ulama. Sesungguhnya Allah Maha Perkasa lagi Maha Pengampun (QS. Fațir [35]: 28)

Ayat tersebut memberikan sebuah keteladan yang digambarkan pada sosok ulama sebagai pewaris para Nabi. Dalam tafsīr At-Ṭarabri maksud dari ulama ialah mereka yang takut kepada Allah, sehingga menjaga diri dari adzab dengan taat kepada-Nya. Orang-orang yang mengetahui kekuasaan Allah atas segala sesuatu, dan bahwa Allah bisa 
melakukan apa yang dikehendaki-Nya. Itu karena, barang siapa mengetahui hal itu, maka ia meyakini adzab-Nya atas maksiat yang dilakukannya, sehingga ia takut kepada Allah sekiranya Dia menghukumnya (Aț-Tabari, 2009a ${ }^{21}$, hlm. 534). Sepadan dengan hal itu, AlMaraghi mempertegas bahwa rasa takut diwujudkan dengan bertaqwa terhadap hukum-hukum-Nya. Karena orang yang mengetahui kebesaran-Nyalah, yang akan merasa yakin tentang hukuman Allah atas siapa pun yang bermaksiat kepada-Nya. Maka dia merasa takut kepada Allah karena khawatir mendapat hukuman-Nya (Al-Maraghi, 1992 $\mathrm{c}^{22}$, hlm. 219-220). Inilah sebuah keteladan yang harus kembali diingat dan diikuti, untuk menunaikan seluruh perintah-Nya dengan sebaik mungkin melalui ketaatan kepada Allah dalam menanmkan rasa khasyyah dan kagum kepada-Nya.

(b) Metode 'Ibraћ Maw'izaћ

'Ibraћ dalam Alquran dapat diartikan sebagai suatu upaya untuk mengambil pelajaran dari pengalamanpengalaman orang lain atau dari peristiwa-peristiwa yang terjadi di masa lampau melalui suatu proses berpikir secara mendalam, sehingga menimbulkan kesadaran pada diri seseorang (Syahidin, 2009, hlm. 110).

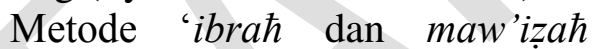
diistilahkan oleh al-Nahlawi (Syahidin, 2009, hlm. 117) sebagai pendekatan pendidikan keimanan dalam Alquran atau disebut sebagai metode Qurāniyyaћ yang memiliki berbagai keistimewaan karena ada keselarasan dengan fitrah manusia sebagai pendidik dan terdidik.

Dalam penelitian ini, ayat yang mengandung metode 'Ibraћ Maw'izaћ adalah QS. Al-Māidah [5]:8 sebagai berikut:

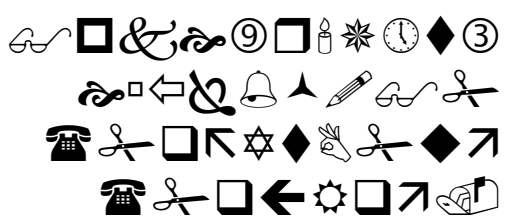

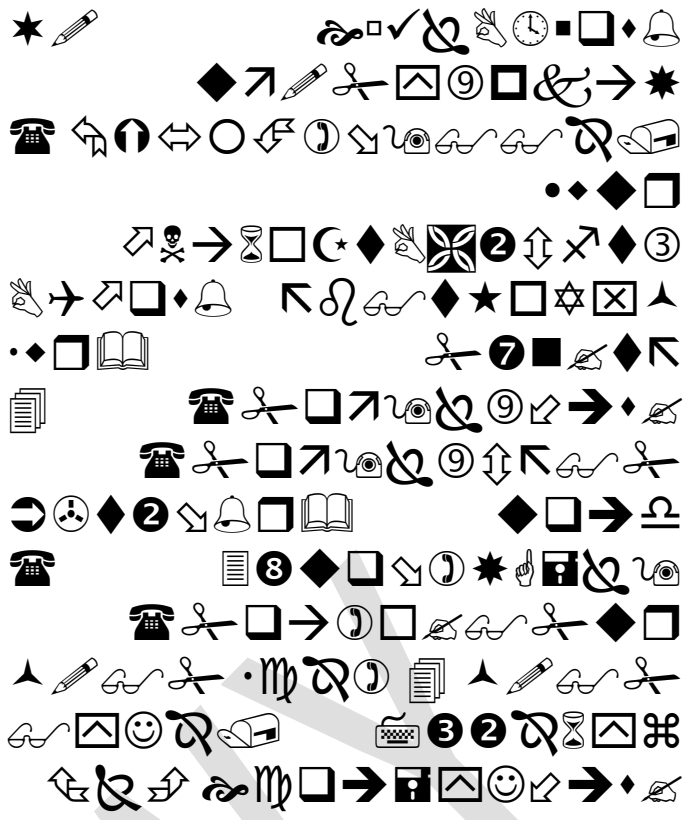

Hai orang-orang yang beriman hendaklah kamu Jadi orang-orang yang selalu menegakkan (kebenaran) karena Allah, menjadi saksi dengan adil. dan janganlah sekali-kali kebencianmu terhadap sesuatu kaum, mendorong kamu untuk berlaku tidak adil. Berlaku adillah, karena adil itu lebih dekat kepada takwa. dan bertakwalah kepada Allah, Sesungguhnya Allah Maha mengetahui apa yang kamu kerjakan (QS. Al-Māidah [5]:8).

Dalam ayat tersebut, mengandung sebuah pelajaran dan nasehat untuk orang-orang yang beriman. Pelajaran yang dapat diambil terdapat dari redaksi kalimat "Janganlah sekali-kali kebencianmu terhadap sesuatu kaum, mendorong kamu untuk berlaku tidak adil", karena dalam Tafsīr Al-Maraghi dijelaskan bahwa ketidak adilan itu mengantarkan kepada perbuatan yang dosa, sehingga mengakibatkan kerusakan bahkan bisa sampai merobek aturan masyarakat. Inilah pelajaran yang dapat kita ambil untuk senantiasa berlaku adil, baik dalam menetapkan hukum, ucapan maupun perbuatan.

Adapun nasehat terdapat dalam redaksi kata "bertaqwalah kamu kepada Allah". Kalimat ini merupakan sebuah nasehat serta perintah yang ditujukan 
Allah untuk orang-orang yang beriman. Dalam tasfir Al-Azhar ditegaskan bahwa keadilan merupakan pintu terdekat menuju taqwa (Hamka, 1983, hlm. 551). Sedangkan Ibn Asyur (1984b ${ }^{6}$, hlm. 135) mengatakan bahwa keadilan yang dimaksud ialah menguasai gejolak jiwa dari syahwat dan itu adalah kekuasaan taqwa. Inilah pelajaran serta nasehat yang harus ditanamkan dalam kontek pendidikan, agar dapat membentuk pribadi seseorang menuju kesempurnaan taqwa.

(c) Targib

Targib adalah strategi atau cara untuk meyakinkan seseorang terhadap kebenaran Allah melalui janji-Nya yang disertai dengan bujukan dan rayuan untuk melakukan amal shaleh (Syahidin, 2009, hlm. 125).

Dalam penelitian ini, ayat yang mengandung metode Targib adalah QS. Al-Mujādillaћ [58]:11 sebagai berikut:

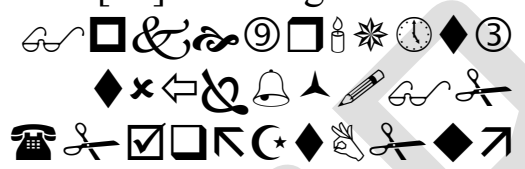

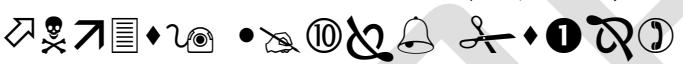

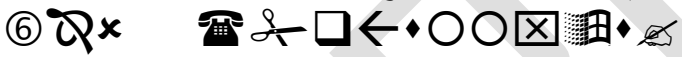

$\Leftrightarrow$ ㄴ.

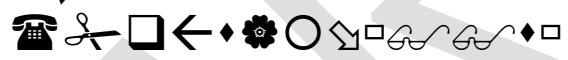

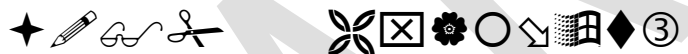

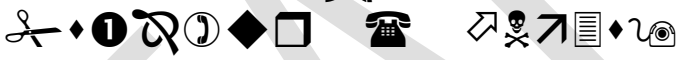
- (10)大

番 \& $\square \downarrow 8 \rightarrow \phi$ of

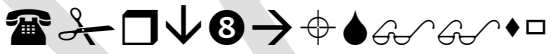

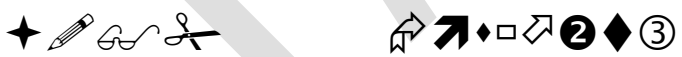

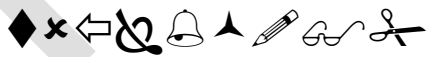

क्षां

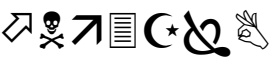

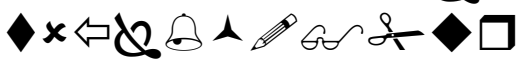
क्षिं

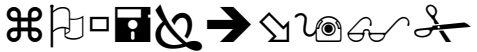

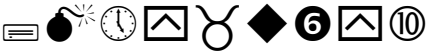

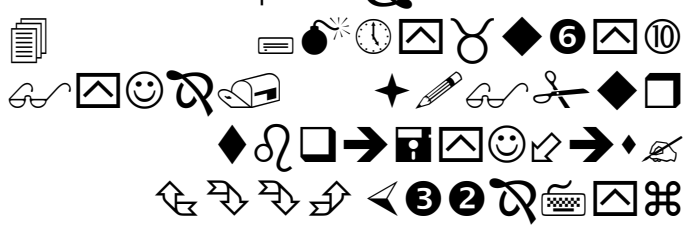

Hai orang-orang beriman apabila kamu dikatakan kepadamu: "Berlapanglapanglah dalam majlis", Maka lapangkanlah niscaya Allah akan memberi kelapangan untukmu. dan apabila dikatakan: "Berdirilah kamu", Maka berdirilah, niscaya Allah akan meninggikan orang-orang yang beriman di antaramu dan orang-orang yang diberi ilmu pengetahuan beberapa derajat. dan Allah Maha mengetahui apa yang kamu kerjakan (QS. Al-Mujādillaћ [58]:11).

Ayat tersebut mengandung sebuah metode Qur'ani yakni metode Targib, yang dilihat dari dua redaksi kalimat berikut; "Maka lapangkanlah niscaya Allah akan memberi kelapangan untukmu", "Berdirilah, niscaya Allah akan meninggikan orang-orang yang beriman di antaramu dan orang-orang yang diberi ilmu pengetahuan beberapa derajat". Dua redaksi kalimat tersebut, berasumsikan bahwa Allah memberikan peringatakan kepada orang-orang yang beriman, dengan cara memberikan balasan bagi orang-orang yang melakukan perintah-Nya melalui janjijanji yang tertulis dalam firman-Nya tersebut, cara ini merupakan sebuah cara untuk meyakinkan seseorang untuk melaksanakan apa yang telah Allah perintahkan disertai bujukan atau rayuan berupa balasan kemulian di sisi Allah. Begitu pun dalam kontek pendidikan, metode ini dapat diterapkan untuk memberikan motivasi serta pengaruh yang positif dalam kehidupan.

\section{Media Pembelajaran Pendidikan Islam}

Berbicara mengenai media sebagai alat bantu, dalam konsep Ūlūl 'ilmi terdapat berbagai macam sarana yang menunjang seseorang untuk memperoleh ilmunya, hal ini termaktub dalam QS. An-Nahl ayat 78 berikut; 
जी

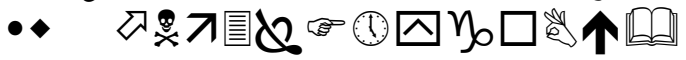

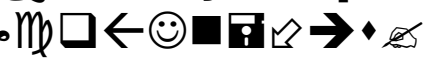
Gr ॐ

К:

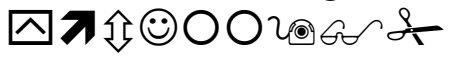
(2) (1) एक

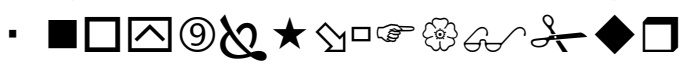

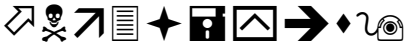

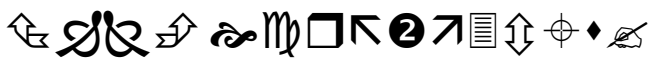
"Dan Allah mengeluarkan kamu dari perut ibumu dalam Keadaan tidak mengetahui sesuatupun, dan Dia memberi kamu pendengaran, penglihatan dan hati, agar kamu bersyukur" (QS. An-Nahl [16]:78)

Ayat tersebut berasumsikan bahwa Alquran memberikan jawaban mengenai empat sarana untuk meraih ilmu, yaitu pendengaran, penglihatan, akal dan hati. Empat sarana tersebut merupakan media Islami yang mutlak diberikan Allah untuk digunakan sebaik mungkin agar memperoleh kebenaran yang objektif. Begitu pun dalam QS. Alī -Imrān [3]:18 dan QS. Fațir [35]:28 terlihat mengandung media atau sarana untuk meraih ilmu, diantara ayatnya sebagai berikut:

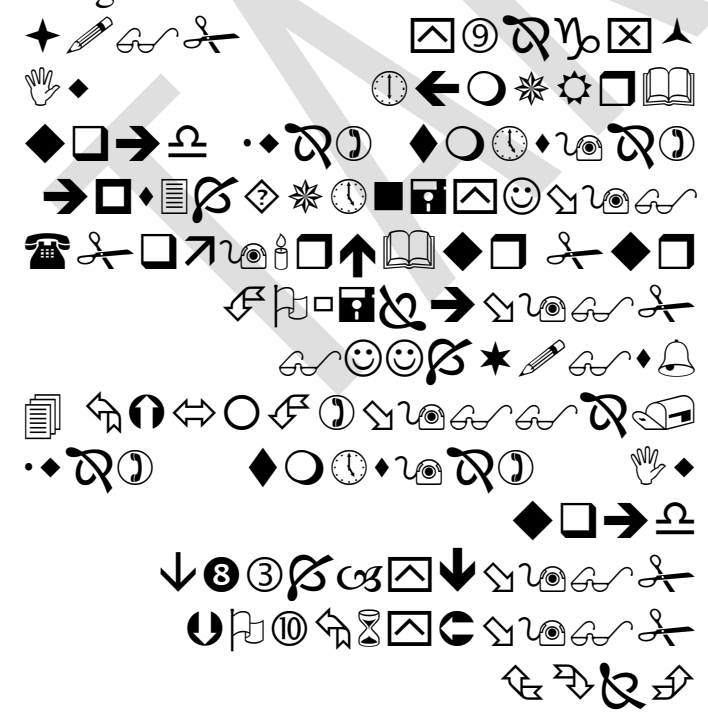

"Allah menyatakan bahwasanya tidak ada Tuhan melainkan Dia (yang berhak disembah), yang menegakkan keadilan. Para Malaikat dan orang-orang yang berilmu (juga menyatakan yang demikian itu). tak ada Tuhan melainkan Dia (yang berhak disembah), yang Maha Perkasa lagi Maha Bijaksana" (QS. Alī -Imrān [3]:18).

$$
\begin{aligned}
& \text { (6) } \\
& \text { पDan demikian (pula) di antara } \\
& \text { manusia, binatang-binatang melata dan } \\
& \text { binatang-binatang ternak ada yang } \\
& \text { bermacam-macam warnanya (dan } \\
& \text { jenisnya). Sesungguhnya yang takut } \\
& \text { kepada Allah di antara hamba-hamba- } \\
& \text { Nya, hanyalah ulama. Sesungguhnya } \\
& \text { Allah Maha Perkasa lagi Maha } \\
& \text { Pengampun"(QS. Fatir [35]:28). }
\end{aligned}
$$

Ayat tersebut mengindikasikan adanya media atau sarana untuk meraih ilmu, dalam QS. Al̄̄ -Imrān [3]:18, redaksi kata "syahada" terlihat bahwa media yang dipergunakan ialah hati sebagai penggerak akal. Walaupun demikian, dalam persaksian ini dibutuhkan media penglihatan untuk menumbuhkan keyakinan akan kekuasaan-Nya melalui alam semeta. Adapun dalam QS. Fațir [35]:28, terlihat sebuah media yang dipergunakan ialah bukan hanya alam, namun ciptaan-Nya diantara manusia, binatang melata serta binatang ternak yang memiliki keberagaman.

Pemaparan tersebut, memberikan suatu pemahaman bahwa pendengaran, 
penglihatan, mata dan hati, dapat diartikan sebagai jendela atau alat dan media yang berfungsi untuk memahami segala hal yang bersifat empiris dan intuitif. Namun bukan hanya itu saja, alam semesta serta makhluk ciptaanNya dapat menjadi media murni untuk meyakini kekuasaan-Nya yang begitu luas. Hal ini mengindikasikan bahwa proses pendidikan dituntut untuk mampu memberdayakan sumber belajar berupa media pembelajaran dengan memanfaatkan alat indra, alam semesta serta makhluk ciptaan-Nya tersebut. Artinya, seorang pendidik harus memiliki keterampilan dalam berinovasi untuk mengembangkan media pembelajaran agar nampak menarik untuk peserta didik, sehingga proses pembelajaran berjalan efektif dan materi yang disampaikan mudah dipahami peserta didik. Kemudian yang perlu diperhatikan kembali, bahwa proses pendidikan bukan hanya sekedar transfer pengetahuan saja, melainkan transfer nilai yang utama. Maka pemilihan dan penetapan media harus mampu mengintegrasikan kedua hal tersebut.

\section{KESIMPULAN}

Berdasarkan hasil analisis dan pembahasan dalam penelitian ini, dapat disimpulkan bahwa makna Ûlūl 'ilmi dalam Tafsīr Mu'tabaroh ialah seseorang yang memiliki ilmu berdasarkan realitas, berwawasan luas, kecerdasannya mampu mencapai makrifat, dan hatinya teguh bertauhid karena memiliki tingkatan khasyyah seperti para ulama. Ilmu yang dimaksud tidak sebatas ilmu agama saja, melainkan ilmu rasional serta ilmu empiric yang dapat mengantarkan keteguhan tauhid di dalam hatinya. Maka dari itu, sosok Ūlūl 'ilmi harus memiliki karakteristik yang berbeda dengan yang lain, yakni memiliki nuansa Ilāhiyyah, spiritual dan bathiniyyah. Karakteristik ini mencangkup pada enam ranah, yakni ranah kognitif, ranah afektif, ranah psikomotorik, ranah sosial, ranah etika dan ranah spiritual. Namun, yang menjadi kunci utama karakteristik $\bar{U} l \bar{u} l$ 'ilmi ialah menghasilkan khasyyah yang kuat terhadap Rabb-nya, sebagai sebab ilmu yang dimilikinya.

Tafsīr

Mu'tabaroh menggambarkan beberapa peran dan fungsi Ûlūl 'ilmi. Esensi yang paling utama dalam peran dan fungsi tersebut ialah membina jiwa, akal dan hati, baik untuk dirinya maupun untuk umat manusia menjadi terarah, sehingga terciptanya keseimbangan jasmani dan rohani dalam berbagai aspek kehidupan. Dengan demikian, orang yang berilmu dalam konsep Alquran bukan sematamata yang memiliki banyak pemikiran, ide serta gagasan. Namun, orang yang berilmu harus mampu memberikan pengaruh hidup serta motivasi positif untuk mengarahkan umat menuju pencapaian hakikat Rabb-nya. Inilah fungsi yang utama, seseorang yang bertindak setelah mengetahui ilmunya. Karena ilmu menjadi landasan utama ketika beramal.

Keseluruhan konsep itu memiliki implikasi teoritis terhadap pendidikan Islam. Implikasi tersebut meliputi pendidik, peserta didik, tujuan pendidikan, peran dan fungsi pendidikan, prinsip-prinsip pendidikan, materi pendidikan, metode pendidikan dan media pendidikan. Kesemuanya itu harus memberikan pengaruh positif pada akal dan hati agar dapat meningkatkan rasa kagum dan kasyyah kepada Allah SWT.

\section{REFERENSI}


Abdussalam, A. (2011). Disertasi; Pembelajaran dalam Al-Qur'an Al-Karim. Bandung.

Ainissyifa, H. (2014). Pendiidkan Karakter dalam Perspektif Pendidikan Islam. Jurnal Pendidikan Universitas Garut Vol.8 No.1. hlm. 1-26.

Al-Maraghi, A. M. (1974c $\left.{ }^{22}\right)$. Tafsir AlMaraghi Juz XXII. Semarang: PT Karya Toha Putra Semarang.

Arifin, M. (2008). Ilmu Pendidikan Islam Tinjauan Teoretis dan Praktis Berdasarkan Pendekatan Interdisipliner. Jakarta: Bumi Aksara.

'Asyur, A. M. $\left(1984 \mathrm{a}^{3}\right)$. Tafsir At-Tahrir Wa Tanwir Juz 3. Tunisi : Dar AtTunisiyah.

$\left(1984 b^{6}\right)$. Tafsir AtTahrir Wa Tanwir Juz 6. Tunisi : Dar At-Tunisiyah.

$\left(1984 \mathrm{c}^{22}\right)$. Tafsir AtTahrir Wa Tanwir Juz 22. Tunisi : Dar At-Tunisiyah.

Ath-Thabari, A. J. $\left(2009 \mathrm{c}^{21}\right)$. Tafsir AthThabari Jilid 21. Jakarta: Pustaka Azzam

Fitri, H. (2013, April 30). Kajian Semantik Ulul Ilmi. Diakses kembali dari http://pkupihimapersis.blogspot.co.id/2013/04 /kajian-semantikkonsep-ulul-ilmidalam.html.

Hamka. (1983). Tafsir Al-Azhar Juz 1, 2 dan 3. Jakarta: Pustaka Panjimas.

Hamka. (1988). Tafsir Al-Azhar Juz XXI. Jakarta: Pustaka Panjimas.

Khoirunnisa. (2012). Profil Kompetensi Guru Pendidikan Agama Islam . Jurnal Tarbawi Vol. 1 No.3 .hlm. 205-219.
Muliawan, J. U. (2005). Pendidikan

Islam Integratif. Yogjakarta: Pustaka

Pelajar

Nata, A. (2010). Ilmu Pendidikan Islam. Jakarta: Kencan Prenada Media Group.

Nata, A. (2003). Manajemen Pendidikan. Jakarta: Prenada Media.

Qordhawi, Y. (1998). Berinteraksi dengan Al-Qur`an. Bandung: Mizan.

Rizal, A. S. (2014). Filsafat Pendidikan Islam Sebagai Landasan Membangun Sistem Pendidikan Islami. Jurnal Pendidikan Agama Islam-Ta'lim Vol.12 No.1 .hlm. 118.

Rizal, A. S. (2014). Perumusan Tujuan Sebagai Basis Pengembangan Kurikulum Pendidikan Islam. Jurnal Pendidikan Agama IslamTa'lim Vol.12 No.2 .hlm. 97-112.

Shihab, M. Q. (1999). Wawasan AlQuran. Bandung: Mizan.

$$
\left(2002 \mathrm{a}^{1}\right) . \quad \text { Tafsir } A l-
$$

Misbah Vol 1. Jakarta: Lentera Hati. - $\left(2002 \mathrm{c}^{11}\right)$. Tafsir AlMisbah Vol 11. Jakarta: Lentera Hati.

Sugiyono. (2011). Metode Penelitian Kuantitatif, Kualitatif dan $R \& D$. Bandung: Alfabeta.

Sukmadinata, N.S. (2012). Metode Penelitian Pendidikan. Bandung : PT Remaja Rosdakarya.

Supadie, D. A. (2011). Pengantar Studi Islam. Jakarta: PT Raja Grafindo Persada

Syahidin, D. H. (2009). Menelusuri Metode Pendidikan dalam AlQuran. Bandung: CV ALFABET.

Ulum, M. (2011). Konsep Ulul Albab QS Ali-Imron Ayat 190-195 \& Relevansinya dengan Tujuan 
Pendidikan. [Skripsi] .Semarang: Insitutt Agama Islam Negeri Walisonggo .

Umar, B. (2012). Hadis Tarbawi

Pendidikan dalam Perspektif

Hadis . Jakarta: Amzah.

Mujib, A., \& Mudzakkir, J. (2008). Nuansa-Nuansa Psikologi Islam . Jakarta: PT. Raja Grafindo.

Nurbaethy, A. (2012). Ilmu dan

Makrifah dalam Al-Qur`an.
Jurnal Al-Fikr Vol 16 No 1, hlm. 163-175.

Tabel-Tabel

Tabel Klasifikasi Karakter Ūlūl ‘ilmi

\begin{tabular}{|c|c|c|c|c|c|}
\hline Kognitif & Afektif & $\begin{array}{c}\text { Psikomo } \\
\text { torik }\end{array}$ & Sosial & Etika & Spiritual \\
\hline $\begin{array}{l}\text { Memiliki } \\
\text { ketajaman } \\
\text { akal }\end{array}$ & $\begin{array}{l}\text { Memiliki } \\
\text { rasa kasih } \\
\text { sayang }\end{array}$ & $\begin{array}{l}\text { Bersikap } \\
\text { adil }\end{array}$ & $\begin{array}{l}\text { Memberi } \\
\text { dorongan } \\
\text { posotif }\end{array}$ & $\begin{array}{l}\text { Budi } \\
\text { bahasa } \\
\text { yang baik }\end{array}$ & $\begin{array}{l}\text { Memiliki aqidah } \\
\text { yang kokoh }\end{array}$ \\
\hline $\begin{array}{l}\text { Memiliki } \\
\text { ilmu yang } \\
\text { memadai }\end{array}$ & $\begin{array}{l}\text { Memiliki } \\
\text { semangat } \\
\text { yang tinggi }\end{array}$ & $\begin{array}{l}\text { Bersikap } \\
\text { bijaksana }\end{array}$ & $\begin{array}{l}\text { Memelihara } \\
\text { wasiat }\end{array}$ & $\begin{array}{l}\text { Sopan } \\
\text { santun }\end{array}$ & $\begin{array}{l}\text { Memiliki iman } \\
\text { yang kuat }\end{array}$ \\
\hline $\begin{array}{l}\text { Memiliki } \\
\text { hujjah dan } \\
\text { bukti }\end{array}$ & & $\begin{array}{l}\text { Bersikap } \\
\text { lapang dada }\end{array}$ & $\begin{array}{l}\text { Memelihara } \\
\text { hubungan } \\
\text { harmonis }\end{array}$ & $\begin{array}{l}\text { Memiliki } \\
\text { tabiat yang } \\
\text { lurus }\end{array}$ & $\begin{array}{l}\text { Memiliki hati } \\
\text { yang suci }\end{array}$ \\
\hline & & & & & $\begin{array}{l}\text { Memiliki sikap } \\
\text { khasyyah, } \\
\text { zuhud, tawadhu, } \\
\text { wara', syukur, } \\
\text { ikhlas, dan taat }\end{array}$ \\
\hline
\end{tabular}


Tabel Keselaran Antara Peran dan Fungsi Ilmu dengan Peran dan Fungsi Ūlūl 'ilmi

\begin{tabular}{|c|c|}
\hline Peran dan Fungsi Ilmu & Peran dan Fungsi $\bar{U} l \bar{l} l$ 'ilmi \\
\hline Meningkatkan Spiritual & $\begin{array}{l}\text { - } \quad \text { Membina jiwa, akal dan hati. } \\
\text { - } \quad \text { Memelihara wasiat dengan menunaikan perintah-Nya. } \\
\text { - } \quad \text { Mengungkap rahasia keesaan Allah. } \\
\text { - } \quad \text { Sengungkap realitas kebenaran ilmu. } \\
\text { - Sebagai fasilitator bertaqarub kepada Allah. } \\
\text { - Sebagai fasilitator untuk meraih derajat taqwa dan } \\
\text { kemuliaan diri di hadapan Allah. }\end{array}$ \\
\hline Penataan Hidup & $\begin{array}{l}\text { - } \text { Memberikan hujjah dan bukti. } \\
\text { - Menegakan keadilan dan kebenaran. } \\
\text { - Menjalin silautahmi yang harmonis. } \\
\text { - } \quad \text { Semberikan pengaruh positif dan motivasi. } \\
\text { syurga. } \\
\text { - Sebagai fasilitator untuk mempermudah jalan menuju } \\
\text { yaumil akhir. } \\
\text { - Sebagai fasilitator untuk meraih rezeki dan rahmat Allah. }\end{array}$ \\
\hline $\begin{array}{l}\text { Pencapaian Kebahagiaan } \\
\text { Lahir dan Batin }\end{array}$ & $\begin{array}{l}\text { - Menumbuhkan rasa cinta dan khasyyah kepada Allah. } \\
\text { - } \\
\text { - } \\
\text { - } \\
\text { - Sebumbina keseimban fasilitator untuk meraih kemenangan dunia } \\
\text { akhirat. } \\
\text { - Sebagai fasilitator untuk meraih kelapangan dan martabat } \\
\text { di sisi Allah. }\end{array}$ \\
\hline Dinamisasi Peradaban & $\begin{array}{l}\text { - } \quad \text { Membina akhlakul karimah. } \\
\text { - } \quad \text { Mengingatkan dalam berjihad dan berbuat kebaikan. } \\
\text { - } \quad \text { Menciptakan keteraturan dan kedamaian. } \\
\text { - } \quad \text { Sebagai fasilitator penebar kemaslahatan. }\end{array}$ \\
\hline
\end{tabular}

Kompetensi Pendidikan dalam Konsep Ūlūl ‘ilmi

\begin{tabular}{|l|l|l|}
\hline \multicolumn{1}{|c|}{ Spiritual } & \multicolumn{1}{|c|}{ Pengetahuan } & \multicolumn{1}{c|}{ Sosial } \\
\hline $\begin{array}{l}\text { Membina jiwa dan hati agar } \\
\text { terarah menuju jalan yang } \\
\text { benar. }\end{array}$ & $\begin{array}{l}\text { Membina akal dengan } \\
\text { baik dan benar. }\end{array}$ & $\begin{array}{l}\text { Memelihara wasiat (amanah) } \\
\text { dengan baik. }\end{array}$ \\
\hline $\begin{array}{l}\text { Membina niat agar selalu } \\
\text { bertauhid. }\end{array}$ & $\begin{array}{l}\text { Memberikan hujjah dan } \\
\text { bukti. }\end{array}$ & $\begin{array}{l}\text { Mengingatkan dalam berbuat } \\
\text { kebaikan. }\end{array}$ \\
\hline $\begin{array}{l}\text { Menumbuhkan cinta dan } \\
\text { khasyyah kepada Allah. }\end{array}$ & $\begin{array}{l}\text { Mengungkap realitas } \\
\text { kebenaran ilmu. }\end{array}$ & $\begin{array}{l}\text { Menegakan keadilan dan } \\
\text { kebenaran. }\end{array}$ \\
\hline $\begin{array}{l}\text { Meneguhkan keyakinan dalam } \\
\text { naungan iman. }\end{array}$ & $\begin{array}{l}\text { Menciptakan keteraturan dan } \\
\text { kedamaian. }\end{array}$ \\
\hline $\begin{array}{l}\text { Mengungkap rahasia keesaan } \\
\text { Allah. }\end{array}$ & $\begin{array}{l}\text { Menjalin silaturahimi yang } \\
\text { harmonis. }\end{array}$ \\
\hline $\begin{array}{l}\text { Membina keseimbangan } \\
\text { jasmani dan rohani. }\end{array}$ & $\begin{array}{l}\text { Memberikan pengaruh positif } \\
\text { dan motivasi. }\end{array}$ \\
\hline
\end{tabular}




\begin{tabular}{|l|l|l|}
\hline Membina akhlakul karimah. & & \\
\hline $\begin{array}{l}\text { Mengarahkan jalan agar selalu } \\
\text { bertaqarub kepada Allah. }\end{array}$ & & \\
\hline $\begin{array}{l}\text { Membina diri menjadi pribadi } \\
\text { yang bertaqwa. }\end{array}$ & & \\
\hline
\end{tabular}

